\title{
Crystal Growth and Nucleation in Glasses in the Lithium Silicate System
}

\author{
Galina A. Sycheva \\ Grebenshchikov Institute of Silicate Chemistry, Russian Academy of Sciences, St. Petersburg, Russia \\ Email: Sycheva_galina@mail.ru
}

How to cite this paper: Sycheva, G.A. (2016) Crystal Growth and Nucleation in Glasses in the Lithium Silicate System. Journal of Crystallization Process and Technology, 6, 29-55.

http://dx.doi.org/10.4236/jcpt.2016.64004

Received: May 26, 2016

Accepted: October 22, 2016

Published: October 25, 2016

Copyright $\odot 2016$ by author and Scientific Research Publishing Inc. This work is licensed under the Creative Commons Attribution International License (CC BY 4.0).

http://creativecommons.org/licenses/by/4.0/ (c) (i) Open Access

\begin{abstract}
The crystal growth and nucleation in glasses in the lithium silicate system have been investigated. Phase separation in ultimately homogenized glasses of the lithium silicate system $x \mathrm{Li}_{2} \mathrm{O} \cdot(100-x) \mathrm{SiO}_{2}$ (where $x=23.4,26.0,29.1$, and $33.5 \mathrm{~mol} \% \mathrm{Li}_{2} \mathrm{O}$ ) has been studied. The glasses of these compositions have been homogenized using the previously established special temperature-time conditions, which make it possible to provide a maximum dehydration and removal of bubbles from the glass melt. The parameters of nucleation and growth of phase separated in homogeneities and homogeneous crystal nucleation have been determined. The absolute values of the stationary nucleation rates $I_{\text {st }}$ of lithium disilicate crystals in the $23.4 \mathrm{Li}_{2} \mathrm{O} \cdot 76.6 \mathrm{SiO}_{2}$, $26 \mathrm{Li}_{2} \mathrm{O} \cdot 74 \mathrm{SiO}_{2}$ and $29.1 \mathrm{Li}_{2} \mathrm{O} \cdot 70.9 \mathrm{SiO}_{2}$ glasses with the compositions lying in the metastable phase separation region have been compared with the corresponding rates $I_{\mathrm{st}}$ for the glass of the stoichiometric lithium disilicate composition $33.51 \mathrm{Li}_{2} \mathrm{O} \cdot 66.5 \mathrm{SiO}_{2}$. It has been found that the crystal growth rate has a tendency toward a monotonic increase with an increase in the temperature, whereas the dependences of the crystal growth rate on the time of low temperature heat treatment exhibit an oscillatory behavior with a monotonic decrease in the absolute value of oscillations. The character of crystallization in glasses with the compositions lying in the phase separation region of the $\mathrm{Li}_{2} \mathrm{O}-\mathrm{SiO}_{2}$ system is compared with that in the glass of the stoichiometric lithium disilicate composition. The conclusion has been made that the phase separation weakly affects the nucleation parameters of the lithium disilicate and has a strong effect on the crystal growth.
\end{abstract}

\section{Keywords}

Phase Separation, Crystal Nucleation, Stationary Nucleation, Crystal Growth in Phase Separated and Non-Phase Separated Glasses 


\section{Introduction}

The glass forming systems may be regarded as model systems for technical glass ceramics. Many papers on investigation of nucleation in oxide glasses are known. Table 1 shows the compound glass-forming systems, for which the temperature dependence of the steady and unsteady crystal nucleation in the bulk nucleation were studied.

As can be seen from Table 1, the greatest attention was paid by researchers to the system $\mathrm{Li}_{2} \mathrm{O}-\mathrm{SiO}_{2}$ [1]-[68] because of its practical importance. A specific feature of the system $\mathrm{Li}_{2} \mathrm{O}-\mathrm{SiO}_{2}$ is that, in the region of compositions from 0 to $32 \mathrm{~mol} \% \mathrm{Li}_{2} \mathrm{O}$, the glasses have a tendency towards the phase separation. Many authors [91]-[94] have believed that the process of phase separation of glasses into two vitreous phases favors a homogeneous crystallization of a glass with the formation of small crystals. As follows from [95] [96], the role of the phase separation is reduced to the appearance of phase boundaries that serve as a particular catalyst of the crystallization. According to [93],

Table 1. Compound of glass-forming systems, for which the temperature dependences of the steady and unsteady crystal nucleation in the bulk nucleation were studied.

\begin{tabular}{|c|c|c|}
\hline Nucleated compound & System & No. references \\
\hline \multicolumn{3}{|c|}{ The system $\mathrm{Li}_{2} \mathrm{O}-\mathrm{SiO}_{2}[1]-[67]$} \\
\hline \multicolumn{3}{|c|}{ Glasses of the stoichiometric composition } \\
\hline $\mathrm{Li}_{2} \mathrm{O} \cdot 2 \mathrm{SiO}_{2}$ & $\mathrm{Li}_{2} \mathrm{O}-\mathrm{SiO}_{2}$ & $\begin{array}{l}{[15]-[17][20]-[24][27][28]} \\
{[32][35][39][46][52][68]}\end{array}$ \\
\hline $\mathrm{Li}_{2} \mathrm{O} \cdot \mathrm{SiO}_{2}$ & $\mathrm{Li}_{2} \mathrm{O}-\mathrm{SiO}_{2}$ & [40] \\
\hline $\mathrm{Na}_{2} \mathrm{O} \cdot 2 \mathrm{CaO} \cdot 3 \mathrm{SiO}_{2}$ & $\mathrm{Na}_{2} \mathrm{O}-\mathrm{CaO}-\mathrm{SiO}_{2}$ & [69] [70] \\
\hline $2 \mathrm{Na}_{2} \mathrm{O} \cdot \mathrm{CaO} \cdot 3 \mathrm{SiO}_{2}$ & $\mathrm{Na}_{2} \mathrm{O}-\mathrm{CaO}-\mathrm{SiO}_{2}$ & {$[71][72]$} \\
\hline $\mathrm{BaO} \cdot 2 \mathrm{SiO}_{2}$ & $\mathrm{BaO}-\mathrm{SiO}_{2}$ & {$[73]-[75]$} \\
\hline $\mathrm{CaO} \cdot \mathrm{SiO}_{2}$ & $\mathrm{CaO}-\mathrm{SiO}_{2}$ & {$[76]$} \\
\hline \multicolumn{3}{|c|}{ Glasses of the compositions close to stoichiometric ones } \\
\hline $\mathrm{Na}_{2} \mathrm{O} \cdot \mathrm{SiO}_{2}$ & $\mathrm{Na}_{2} \mathrm{O}-\mathrm{SiO}_{2}$ & {$[77]-[80]$} \\
\hline $\mathrm{Na}_{2} \mathrm{O} \cdot 2 \mathrm{SiO}_{2}$ & $\mathrm{Na}_{2} \mathrm{O}-\mathrm{SiO}_{2}-\mathrm{Cr}_{2} \mathrm{O}_{3}$ & {$[56]$} \\
\hline $\mathrm{BaO} \cdot 2 \mathrm{SiO}_{2}$ & $\mathrm{Na}_{2} \mathrm{O}-\mathrm{BaO}-\mathrm{SiO}_{2}$ & [81] \\
\hline $\mathrm{Na}_{2} \mathrm{O} \cdot 2 \mathrm{CaO} \cdot 3 \mathrm{SiO}_{2}$ & $\mathrm{Na}_{2} \mathrm{O}-\mathrm{CaO}-\mathrm{SiO}_{2}$ & {$[82]-[84]$} \\
\hline \multicolumn{3}{|c|}{ Glasses of the non-stoichiometric compositions } \\
\hline $\mathrm{Li}_{2} \mathrm{O} \cdot \mathrm{SiO}_{2}$ & $\mathrm{Li}_{2} \mathrm{O}-\mathrm{Al}_{2} \mathrm{O}_{3}-\mathrm{SiO}_{2}$ & [85] \\
\hline $\mathrm{MgCr}_{2} \mathrm{O}_{4}$ & $\mathrm{CaO}-\mathrm{MgO}-\mathrm{Al}_{2} \mathrm{O}_{3}-\mathrm{SiO}_{2}$ & {$[86]$} \\
\hline $\mathrm{CaO} \cdot \mathrm{MgO} \cdot 2 \mathrm{SiO}_{2}$ & $\mathrm{CaO}-\mathrm{MgO}-\mathrm{Al}_{2} \mathrm{O}_{3}-\mathrm{SiO}_{2}$ & {$[86]$} \\
\hline $\mathrm{Na}_{2} \mathrm{O} \cdot \mathrm{Al}_{2} \mathrm{O}_{3} \cdot 6 \mathrm{SiO}_{2}$ & $\mathrm{Na}_{2} \mathrm{O}-\mathrm{Al}_{2} \mathrm{O}_{3}-\mathrm{SiO}_{2}$ & [87] \\
\hline $2 \mathrm{SnO} \cdot \mathrm{P}_{2} \mathrm{O}_{5}$ & $\mathrm{SnO}-\mathrm{SnO}_{2}-\mathrm{ZnO}-\mathrm{P}_{2} \mathrm{O}_{5}$ & [88] \\
\hline $\mathrm{Na}_{2} \mathrm{O} \cdot \mathrm{ZnO} \cdot \mathrm{P}_{2} \mathrm{O}_{5}$ & $\mathrm{Na}_{2} \mathrm{O}-\mathrm{ZnO}-\mathrm{P}_{2} \mathrm{O}_{5}$ & [89] \\
\hline $\mathrm{BaO} \cdot \mathrm{B}_{2} \mathrm{O}_{3} \cdot \mathrm{P}_{2} \mathrm{O}_{5}$ & $\mathrm{BaO}-\mathrm{P}_{2} \mathrm{O}_{5}-\mathrm{B}_{2} \mathrm{O}_{3}$ & {$[90]$} \\
\hline
\end{tabular}


the crystallization of phase separated glasses cannot be referred to as catalytic. It is necessary to speak about the influence of the phase separation on a further crystallization process rather than about catalysis. Actually, a review of a number of experimental works [81] [97]-[101] demonstrates that the liquid-liquid phase separation before crystallization affects the crystal structure of glass-ceramic materials through at least three different ways.

1) The boundary between phases plays a role of an initiating agent.

2) Since, after the phase separation, the composition of a matrix or dispersed phase becomes closer to that of a crystallizing phase, the formation and growth of crystals progress more easily.

3) In one of the phases, the metastable phase precipitates and plays a role of a catalyst for the main crystalline phase.

The purpose of this work is to investigate the crystal growth and nucleation in glasses in the lithium silicate and sodium silicate systems that serve as a basis for the preparation of glass ceramic materials.

\section{Sample Preparation and Experimental Technique}

The rates of nucleation and growth of crystals and phase separated in homogeneities were studied in glasses of the analyzed compositions $x \mathrm{Li}{ }_{2} \mathrm{O} \cdot(100-x) \mathrm{SiO}_{2}$ (where $x=$ 23.4, 26.0, 29.1 and $33.5 \mathrm{~mol} \% \mathrm{Li}_{2} \mathrm{O}$ ). Since it was established earlier that the crystal nucleation parameters are strongly affected by water [35] and bubbles formed in the course of glass synthesis [102], the glasses were homogenized to a maximum extent under specially established temperature-time conditions of synthesis. As was previously shown, bubbles can play a role of initiators of nucleation of lithium disilicate crystals and increase a number of crystals to $20 \%$ [103]. As the water content increases, the stationary nucleation rate increases and the position of the maximum shifts toward lower temperatures [35]. In this respect, all cares were taken in order to prepare glasses homogenized to a maximum extent. Water was removed by bubbling glass melts with argon for $20 \mathrm{~min}$ [49]. Bubbles were removed by performing the synthesis at a high temperature. The glasses were synthesized according to the technique described in [103]. A batch was prepared from lithium carbonate (analytical grade) and dehydrated silicon dioxide (analytical grade) by mixing in a drum. The glasses were synthesized in a platinum crucible (volume, $200 \mathrm{ml}$ ) in a Globar-heater furnace with silicon carbide heaters (synthesis temperature, $1550^{\circ} \mathrm{C}$; synthesis time, $5 \mathrm{~h}$ ). Heat treatments were performed in SShOL electric shaft furnaces and a gradient furnace designed at a laboratory. The temperature was maintained accurate to within $\pm 1^{\circ} \mathrm{C}$. The results of the chemical analysis of the synthesized glasses are presented in Table 2.

$\mathrm{X}$-ray powder diffraction analysis was performed on a DRON-2 diffractometer $\left(\mathrm{Cu} K_{\alpha}\right.$ radiation; operating voltage $30 \mathrm{kV}$; current $20 \mathrm{~mA}$; detector rotation rate, $2 \mathrm{deg} / \mathrm{min}$ ). Differential thermal analysis (DTA) was carried out on a MOM derivatograph (heating rate, $10 \mathrm{~K} / \mathrm{min}$; sample weight, $1 \mathrm{~g}$; galvanometer sensitivity, $1 / 5$; reference sample, $\mathrm{Al}_{2} \mathrm{O}_{3}$; platinum crucible). Optical microscopy investigations in transmitted and reflected light 
Table 2. Chemical compositions under investigation ( $\mathrm{mol} \%)$.

\begin{tabular}{ccc}
\hline Glass no. & $\mathrm{Li}_{2} \mathrm{O}$ & $\mathrm{SiO}_{2}$ \\
\hline 1 & 23.4 & 76.6 \\
2 & 26.0 & 74.0 \\
3 & 29.1 & 70.9 \\
4 & 33.5 & 66.5 \\
\hline
\end{tabular}

were performed on Carl Zeiss Jenaval and Neophot 32 microscopes (Germany). Electron microscopy studies were carried out on an EM-125 transmission electron microscope (accelerating voltage, $75 \mathrm{kV}$ ). Samples were prepared using the method of celluloid-carbon replicas. The viscosity was measured by the bending method on a Klyuev viscometer. The temperature dependence data on the viscosity was processed by the least squares technique with the conventional computer program for determining the coefficients $A, B$, and $T_{0}$ in the approximation according to the Vogel-Fulcher-Tammann equation [104]. The nucleation and growth rates of phase separated inhomogeneities and crystals were determined by the development method: preliminary heat treatment of the glass at a low temperature $T$, followed by the development at a higher temperature $T_{\text {dev }}>T$ bringing to sizes that can be fixed in an optical microscope. The crystal growth rate was measured by quenching the samples. The samples in the form of small glass pieces were held at a specified temperature for different times and were used to prepare polished plane parallel disks $0.5 \mathrm{~mm}$ thick. Crystals with a maximum size were found in the bulk of a sample, and their radius $R_{\max }$ was measured using the Jenaval optical microscope. The radius $R_{\max }$ of the phase separated droplet or crystal was taken to be equal to the average value over ten maximum radii of crystals or phase separated droplets. This requires the explanation. If some number of phase separated droplets or crystals in the shape of spheres with the same radius $R$ are randomly distributed in the glass bulk (their number per unit volume is designated as $N$ ), certain crystals or phase separated droplets will be cut by the plane when preparing the cleavage or cross section of the sample. This holds true only for crystals or phase separated droplets with the centers located at a distance that is not larger than $R$ from the cut plane. Therefore, all crystals or phase separated droplets with the centers located in the layer of thickness $2 R$ leave a trace on the cut plane. It is clear that the maximum radius of the trace of the crystal or phase separated droplet will correspond to the real radius of these particles.

\section{Temperature Dependence of the Nucleation and Growth Rate of Phase Separated Inhomogeneities in Lithium Silicate Glasses of the Compositions $23.4 \mathrm{Li}_{2} \mathrm{O} \cdot 76.6 \mathrm{SiO}_{2}(1)$, $26 \mathrm{Li}_{2} \mathrm{O} \cdot 74 \mathrm{SiO}_{2}(2)$, and $29.1 \mathrm{Li}_{2} \mathrm{O} \cdot 70.9 \mathrm{SiO}_{2}(3)$}

In the $33.5 \mathrm{Li}_{2} \mathrm{O} \cdot 66.5 \mathrm{SiO}_{2}$ glass with the composition closest to the stoichiometric composition of the lithium disilicate, excess $\mathrm{SiO}_{2}$ is absent and, therefore, no phase separation is observed. The compositions of the glasses containing $23.4 \mathrm{~mol} \% \mathrm{Li}_{2} \mathrm{O}$ (no. 1), 
26 $\mathrm{Li}_{2} \mathrm{O}$ (no. 2), and $29.1 \mathrm{Li}_{2} \mathrm{O}$ (no. 3) lie in the metastable phase separation region of the lithium-silicate system. The samples of glasses no. 1, no. 2, no. 3 and no. 4 were subjected to preliminary heat treatment at temperatures in the range $370^{\circ} \mathrm{C}-560^{\circ} \mathrm{C}$ for different times. Then, they were held at a development temperature of $600^{\circ} \mathrm{C}$ for 10 min. If glass no. 1 , no. 2 or 3 is held at the temperature $T=600^{\circ} \mathrm{C}$ for a time in the range $0-10 \mathrm{~h}$, it remains transparent without visible opalescence in visual examination. If the glass is heat treated for $t=2 \mathrm{~h} 40 \mathrm{~min}$ at temperatures of $400^{\circ} \mathrm{C}-560^{\circ} \mathrm{C}$, it remains visually transparent and does not become opalescent. After additional heat treatment at $600^{\circ} \mathrm{C}$ for $10 \mathrm{~min}$, the glass acquires bright blue (yellow in transmission) going to milky opalescence. The electron microscopic images of the glasses preliminarily heat treated at temperatures in the range $400^{\circ} \mathrm{C}-560^{\circ} \mathrm{C}$ and developed at $600^{\circ} \mathrm{C}$ for 10 min are displayed in Figures 1(a)-1(c).

We counted the number of traces of particles per unit area in the electron microscopic image $N_{S} / S_{0}$ and determined the sizes of the maximum traces of particles $R$. The corresponding results for glass no. 1 are listed in Table 3.

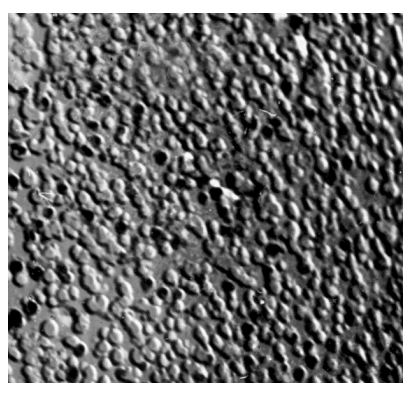

(a)

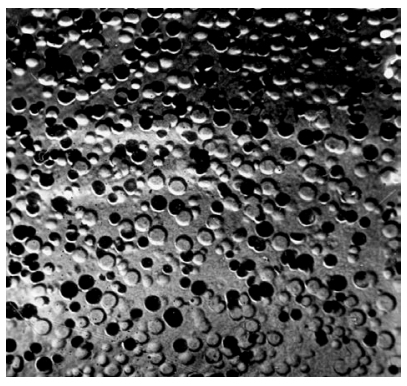

(b)

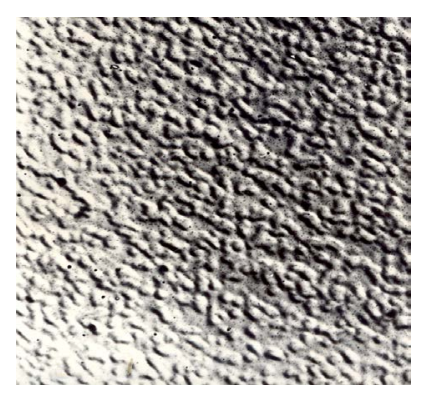

(c)

Figure 1. Electron microscopic images of glasses (a) no. 1, (b) no. 2 and (c) no. 3 preliminarily heat treated at temperature $460^{\circ} \mathrm{C}$ for $2 \mathrm{~h} 40 \mathrm{~min}$ and developed at $600^{\circ} \mathrm{C}$ for $10 \mathrm{~min}$ (magnification, 28,800).

Table 3. Numbers of traces of particles per unit area in electron microscopic images $N_{S} / S_{0}$ and their sizes in glass no. 3 after heat treatment at $T$ for $160 \mathrm{~min}$ and development at $600^{\circ} \mathrm{C}$ for 10 min.

\begin{tabular}{ccc}
\hline$T,{ }^{\circ} \mathrm{C}$ & $N_{s,} \mu \mathrm{m}^{-2}$ & $R, \AA$ \\
\hline 370 & 90 & 103 \\
390 & 108 & 150 \\
400 & 112 & 160 \\
420 & 120 & 190 \\
460 & 134 & 250 \\
464 & 131 & 260 \\
490 & 118 & 300 \\
520 & 94 & 335 \\
540 & 74 & 375 \\
560 & 60 & 408 \\
580 & 48 & 440 \\
\hline
\end{tabular}


Figure 2 presents the quantitative characteristics of the phase separation structure in glasses no. 1 and no. 2 as a function of the temperature, namely, the ratio of the number of traces to the maximum number of traces $N_{S} / N_{S \max }$ and the ratio of the radius of the particle trace to the maximum radius $R / R_{\max }$.

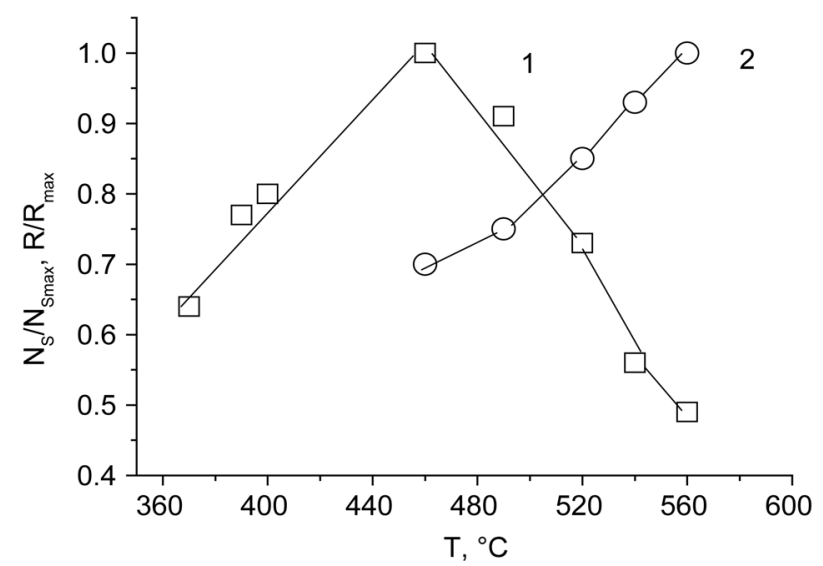

(a)

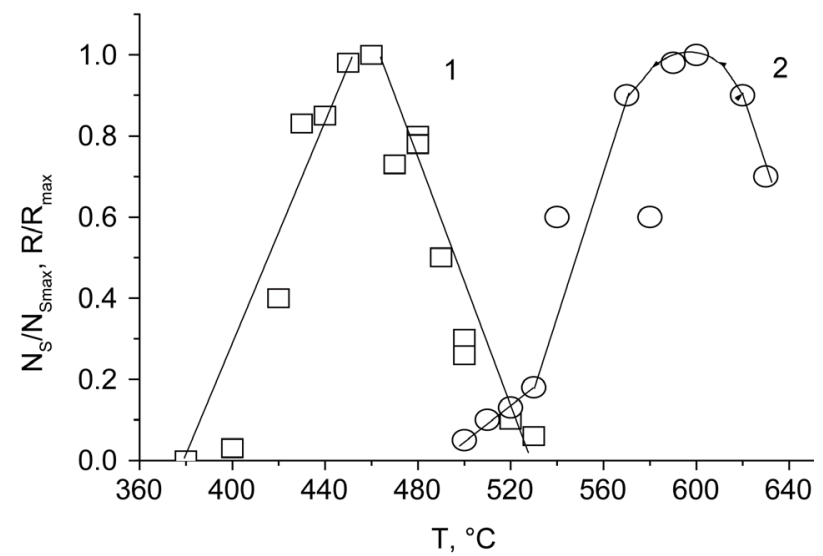

(b)

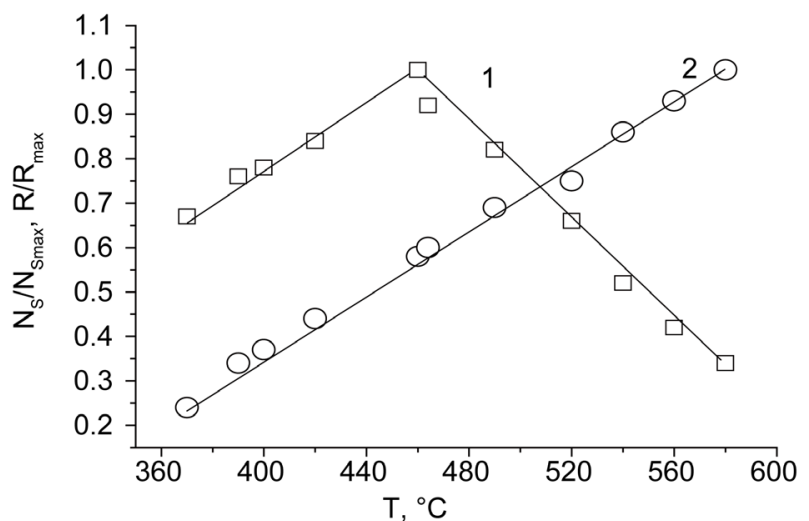

(c)

Figure 2. Quantitative characteristics of the phase separation structure in glasses (a) no. 1, (b) no. 2 and (c) no. 3 as a function of the temperature: (1) ratio of the number of traces to the maximum number of traces $N_{S} / N_{S \max }$ and (2) ratio of the radius of the particle trace to the maximum radius $R / R_{\max }$. 
Here, we assume that the dependence of the number of traces of phase separated droplets per unit area of the sample surface on the heat treatment temperature (at a constant heat treatment time) obeys the same function law as the temperature dependences of the stationary nucleation rate of droplets. Strictly speaking, in order to determine the stationary nucleation rate $I(T)$, initially, it is necessary to determine the number of droplets per unit volume of the glass by the number of traces per unit area with the use of stereological formulas. Then, it is required to determine a variation in the number of droplets per unit volume as a function of the heat treatment time. Thereafter, it is necessary to check that the nucleation rate is stationary and to determine its value. This is not a simple problem, which is complicated by the fact that the droplets in the volume of the glass can have different sizes. The obtained dependence of the number of traces on the temperature for a fixed heat treatment time can differ substantially from the dependence of the stationary nucleation rate of droplets. However, we used a simpler method to approximately evaluate the temperature dependence of the nucleation rate of droplets. Instead of the dependence $I(T)$, we constructed the dependence $N_{S}(T)$ of the number of traces of particles developed for the same specified time of development $t_{\text {dev }}$ at $T_{\text {dev }}$ after preliminary heat treatment for the same specified time $t$ at all temperatures $T$. Since the quantities $I$ and $N_{S}$ are approximately proportional to each other, the curves $I(T) / I_{\max }$ and $N_{S}(T) / N_{S \max }$ are very close to each other and, in order to evaluate the temperature of the maximum nucleation rate, it is sufficient to measure the dependence of the number traces of crystals $N_{S}$ without regarding for their shape and sizes [77] [80]. It can be seen from Figure 2 that these dependences exhibit maxima. The maximum values of the number of traces and sizes correspond to temperatures of 460 and $600^{\circ} \mathrm{C}$, respectively. On the whole, the results obtained can be explained as follows. The nucleation rate of a new phase (phase separated or crystalline) $I$ has the form [68]

$$
I=A \exp \left[-\left(\Phi_{A}+\Phi^{*}\right) / k T\right]
$$

where $\Phi^{*}$ is the increment of the thermodynamic potential of the glass due to the appearance of a critical (in composition and size) inhomogeneity nucleus, $\Phi_{A}$ is the thermodynamic potential of diffusion jumps and transformations during the phase separation, and $A$ is the factor that, like the quantities $\Phi_{A}$ and $\Phi^{*}$, depends on the glass composition and temperature more weakly than an exponential function. If the glass composition $c_{0}$ belongs to the bimodal region at a given temperature, the thermodynamic potential $\Phi^{\star}$ is relatively high because the inhomogeneities that do not reach some limiting concentration $c_{1}$ appear to be energetically unfavorable irrespectively of their sizes. When the glass composition belongs to the spinodal region, inhomogeneities with an arbitrarily small difference $\left|c-c_{0}\right|$ and, correspondingly, with negligible $\Phi^{*}$ can be energetically favorable if only their size exceeds the critical size. As a consequence, there is an increase in the nucleation rate of inhomogeneities $I$ (expression (1)). By using the notion of the concentration wave length $\lambda$ introduced by Cahn, in the spinodal region, the value $\left|c-c_{0}\right|$ most rapidly increases in amplitude and, hence, the inhomogeneities with the size $\lambda_{m}$ that is larger than the critical size $\lambda_{\text {cr }}$ by a factor of $\sqrt{2}$ nuc- 
leate most rapidly. The wave amplitude $\lambda_{m}$ increases as $\exp \left(t / \tau_{m}\right)$; in this case, the magnitude $1 / \tau_{m}$ can be considered not only as the measure of the nucleation rate of the amplitude but also as the measure of the nucleation rate of inhomogeneities by taking $I=$ $B / \tau_{m}$. As a result, we have (2)

$$
I=\frac{B}{\tau_{m}}=c\left(T_{S}-T\right)^{2} \exp \left(-\frac{\Phi_{A}}{k T}\right),
$$

where $B$ and $c$ are temperature independent constants and $T_{S}$ is the spinodal temperature. From the condition $\mathrm{d} I / \mathrm{d} T=0$, we find that the maximum of the rate is located at the temperature $T_{\max }$ satisfying the Equation (3).

$$
T_{S}-T_{m}=\frac{2 R T_{m}^{2}}{E_{A}\left(T_{m}\right)}, \quad E_{A}(T)=\Phi_{A}(T)-T \frac{\partial \Phi_{A}(T)}{\partial T}
$$

By assuming that the thermodynamic potential $\Phi_{A}$ does not depend on the temperature T, i.e., $\Phi_{A}=E_{A}$, and setting $\Phi_{A}=83 \mathrm{kcal} / \mathrm{mol}$ (activation energy of oxygen diffusion), at $T_{m} \cong 973 \mathrm{~K}$, Equation (3) takes the form

$$
T_{S}-T_{m} \cong T_{m}\left(2 R T_{m} / \Phi_{A}\right) \cong 25 \mathrm{~K}
$$

Under the assumption that the thermodynamic potential $\Phi_{A}$ is equal to the activation energy of lithium self diffusion, we obtain

$$
T_{S}-T_{m} \cong 60 \mathrm{~K}
$$

Therefore, the maximum of the ratio $N_{S} / N_{S \max }$ in Figure 2 reflects the maximum of the nucleation rate of droplets with a diameter $\lambda=200-400 \AA$. This reflection is rather indirect because the number of inhomogeneities $n^{\prime}$ nucleated for the time $t^{\prime} n^{\prime}=\int_{0}^{t^{\prime}} I(t) \mathrm{d} t$ can differ significantly (and differs) from the number $n$ of large particles growing in the course of the development. The reason is that, after the increase in the temperature to $600^{\circ} \mathrm{C}$, the inhomogeneities with the composition and size that reach critical values at $600^{\circ} \mathrm{C}$ are predominantly retained and will develop. The inhomogeneities with the composition that approaches the binodal composition at the corresponding temperature during low temperature heat treatment go beyond the binodal with the increase in temperature to $600^{\circ} \mathrm{C}$ and should dissolve in the glass located between inhomogeneities. A number of inhomogeneities can merge together when reaching the critical sizes for a temperature of $600^{\circ} \mathrm{C}$. This dissolution and merging of small inhomogeneities can lead to the formation of larger and stable inhomogeneities with a composition close to the binodal composition at the temperature of $600^{\circ} \mathrm{C}$.

Although the relation between the quantities $n$ and $n$ is complex, the maximum of the ratio $N_{S} / N_{S \max }$ in Figure 2 reflects the rate of nucleation and development of phase separated inhomogeneities. Then, the temperature of its left boundary $T_{S}^{\prime}$ can be identified with the spinodal temperature $T_{S}$ and the difference between this temperature and the temperature of the maximum $T_{\max }$ is appropriately identified by the difference $T_{S}^{\prime}-T_{\max }$, which was estimated above as $25^{\circ} \mathrm{C}-60^{\circ} \mathrm{C}$. It is difficult to accu- 
rately determine the spinodal temperature. In our experiment, we determined this temperature from the appearance of pronounced phase separated droplets in the electron microscopic images. Experimental data on the determination of the spinodal are absent in the literature.

Haller et al. [105] calculated the spinodal for glasses in the lithium silicate system. A comparison of our data with those obtained in [105] leads to the following results. According to [105], the spinodal temperature $T_{S}$ amounts to approximately $600^{\circ} \mathrm{C}$ for glass no. $1\left(23.4 \mathrm{~mol} \% \mathrm{Li}_{2} \mathrm{O}\right)$ and is in the vicinity of $500^{\circ} \mathrm{C}$ for glass no. $2(26.0 \mathrm{~mol} \%$ $\mathrm{Li}_{2} \mathrm{O}$ ). Below $500^{\circ} \mathrm{C}$, data in [105] are absent. However, if the curve is extrapolated to $400^{\circ} \mathrm{C}$, the spinodal temperature $T_{S}$ for glass no. 2 appears to be $400^{\circ} \mathrm{C}$. In our work, the maximum of the ratio $N_{S} / N_{S \max }$ in Figure 2 lies in the temperature range $350^{\circ} \mathrm{C}-570^{\circ} \mathrm{C}$ for glass no. 1 and $\approx 400^{\circ} \mathrm{C}-650^{\circ} \mathrm{C}$ for glass no. 2. Therefore, the experimental and calculated data for glass no. $2\left(26.0 \mathrm{~mol} \% \mathrm{Li}_{2} \mathrm{O}\right)$ are in good agreement, whereas, for glass no. $1\left(23.4 \mathrm{~mol} \% \mathrm{Li}_{2} \mathrm{O}\right.$ ), the calculated value is by $200^{\circ} \mathrm{C}$ higher than the experimental. For glasses no. 1 and no. 2 , the difference $T_{S}^{\prime}-T_{\max } \cong 40^{\circ} \mathrm{C}-50^{\circ} \mathrm{C}$ actually lies in this range. The maximum of the rate of nucleation and development of inhomogeneities is located at the glass transition temperature $T_{g}$.

In order to compare more rigorously the theory with the experiment, it is necessary to know the spinodal temperature $T_{S}$. This temperature was evaluated as follows. Quenched glasses no. 1 and no. 2 (without low temperature heat treatments) were held in the gradient furnace at temperatures in the range $300^{\circ} \mathrm{C}-800^{\circ} \mathrm{C}$ for $2 \mathrm{~h}$. This led to the appearance of the opalescent band along the sample length, which was stable with respect to a further increase in the holding time. This band had a higher intensity in the central part and weaker intensities toward higher and lower temperatures up to its complete visual disappearance. The temperature of the upper edge of the visible opalescence $\left(770^{\circ} \mathrm{C}\right.$ for glass no. 1) coincided with the phase separation temperature $T_{I}$ $\left(770^{\circ} \mathrm{C}\right.$ for glass no. 1$)$ determined as the temperature of the disappearance of the visible opalescence after the opalescent part of the rod was displaced in the range of temperatures a priori higher than $T_{1}$. The analysis of the electron microscopic images demonstrates that, in going from the high temperature edge of the band to the low temperature edge, the number of particle traces per unit area (or the relative area occupied by particle traces) increases linearly. Initially, this process goes slowly and then accelerates. It is clear because the nucleation rate is minimum in the vicinity of the phase separation temperature $T_{l}$ and increases as the spinodal temperature $T_{S}$ is approached as a result of the decrease in the thermodynamic potential $\Phi^{*}$ in expression (1). When the traces of inhomogeneities begin to cover a larger part of the replica area and to merge together, the increase in the relative area $S / S_{0}$ occupied by particles at $T_{S}^{\prime}$ is retarded sharply. The temperature of this kink in the curve $S / S_{0}$ is naturally identified by the spinodal temperature $T_{S}$ corresponding to the beginning of fast nucleation of inhomogeneities occupying the volume of the glass. This temperature almost absolutely coincides with the low temperature edge of the visible opalescence. The temperature width of the opalescent band $\Delta T_{\mathrm{op}}$ corresponds to the difference $T_{1}-T_{S} \cong \Delta T_{\mathrm{op}}$. 


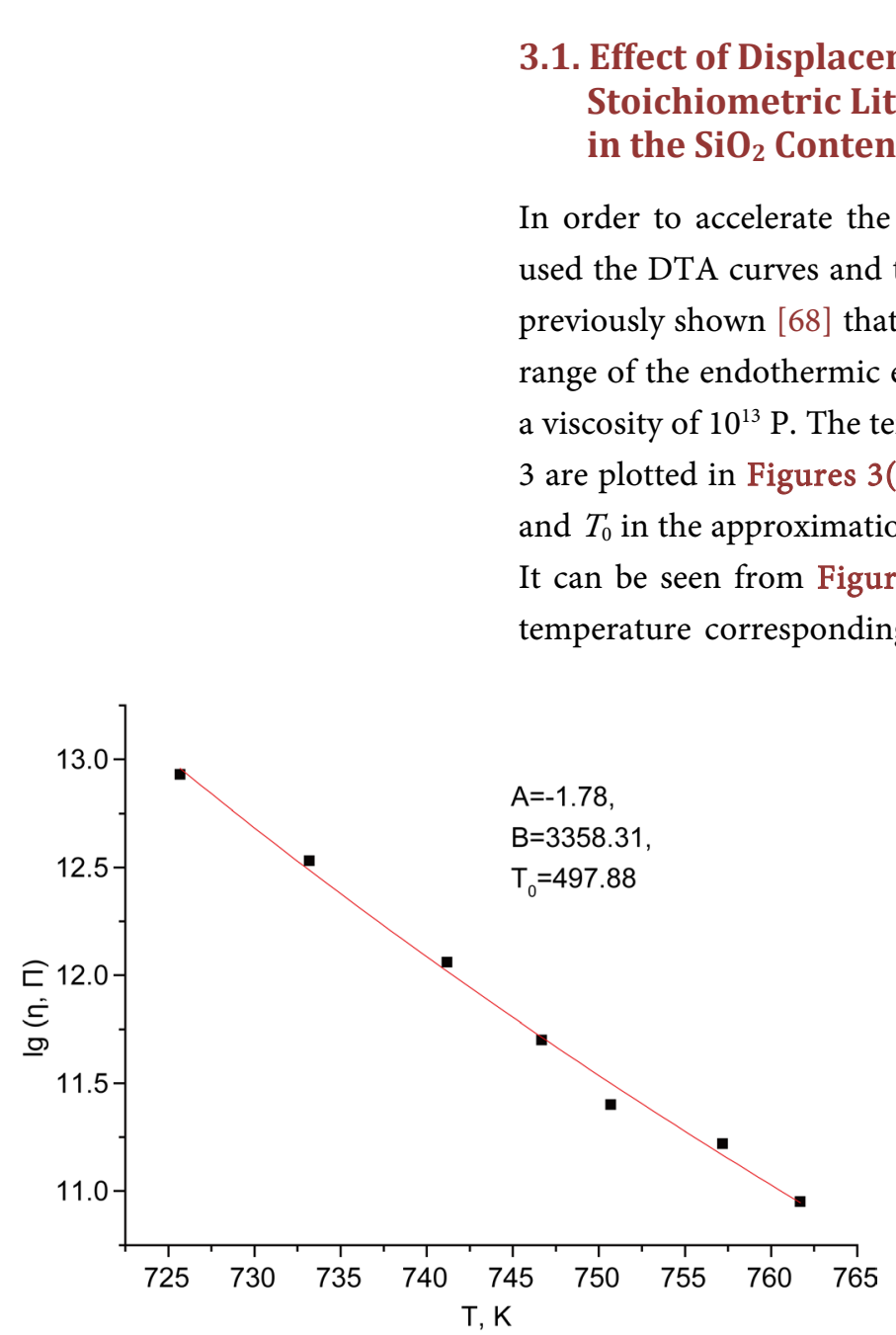

(a)

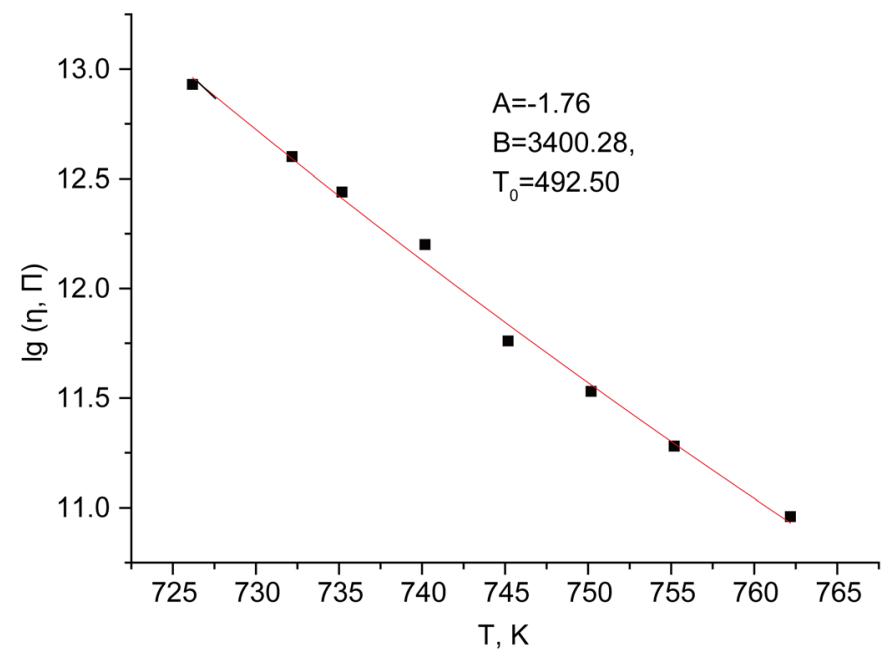

(c)

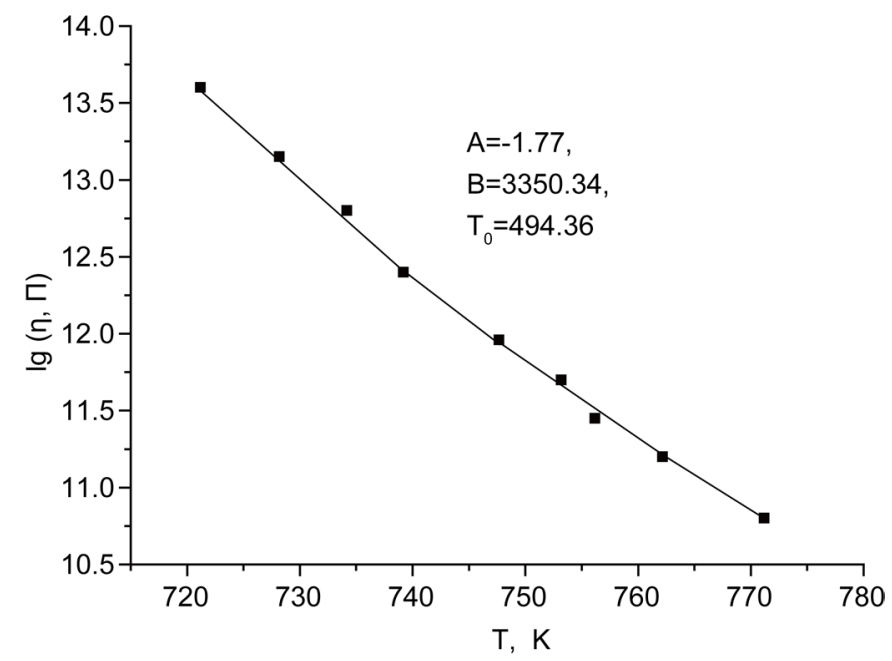

(b)

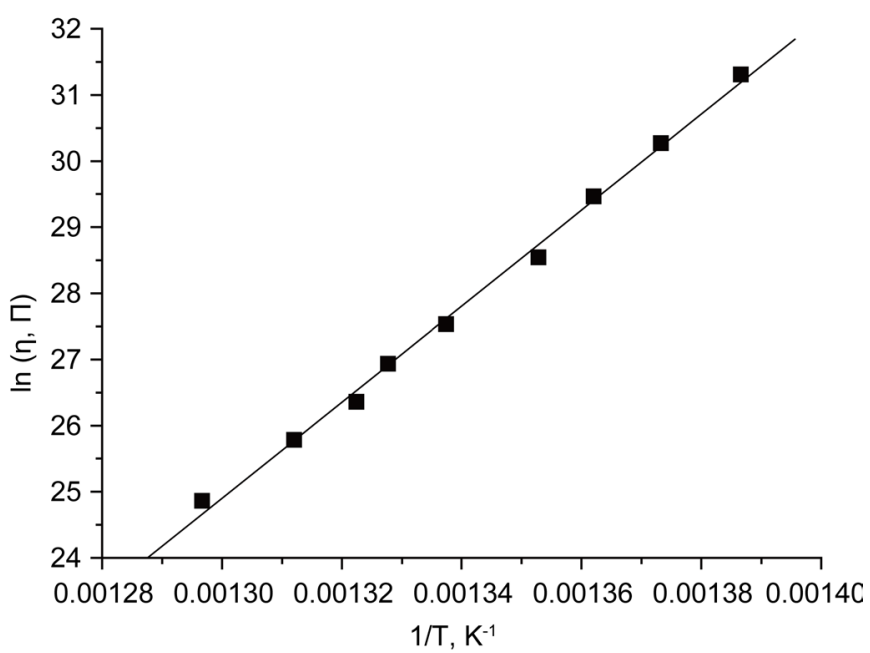

(d)

Figure 3. Temperature dependences of the decimal logarithm of the viscosity for glasses (a) no. 1, (b) no. 2, and (c) no. 3 and (d) temperature dependence of the natural logarithm of the viscosity for glass no. 2 (used for determining the activation energy of viscous flow in the glass). 
$458^{\circ} \mathrm{C}$ for glass no. $2,457^{\circ} \mathrm{C}$ for glass no. 3 and $450^{\circ} \mathrm{C}$ for glass no. 4 . The slope of the temperature dependence of the natural logarithm of the viscosity on the reciprocal of the temperature (Figure 3(d)) was used to determine the activation energies of the viscous flow $E_{\eta}=R d \mathrm{n} \eta / d(1 / T)$, which were equal to $148,149,150$ and $152 \mathrm{kcal} / \mathrm{mol}$ for glasses no. 1 - no. 4 , respectively.

The X-ray powder diffraction data (Figure 4) demonstrate that the initial glasses are $\mathrm{X}$-ray amorphous. The lithium disilicate crystals nucleated at temperatures of preliminary heat treatments in the range $420^{\circ} \mathrm{C}-520^{\circ} \mathrm{C}$ for all times cannot be revealed using $\mathrm{X}$-ray diffraction analysis. This is associated with the fact that the lithium disilicate nuclei are extremely small and their total weight is insignificant and, hence, insufficient for identifying by $\mathrm{X}$-ray diffraction analysis, because its sensitivity is equal to a few weight percent of a compound. After heat treatments, lithium disilicate $\mathrm{Li}_{2} \mathrm{O} 2 \mathrm{SiO}_{2}$ (PCPDFWIN no. 80 - 1470; orthorhombic structure; unit cell parameters $a=5.687 \AA$, $b=4.784 \AA$, and $c=14.640 \AA$ ) crystallizes in glasses no. 1 - no. 3 at a development temperature of $600^{\circ} \mathrm{C}$ for $10 \mathrm{~min}$.

It can be seen from the images obtained using the optical microscope in reflected and transmitted light (Figure 5) that the lithium disilicate grows in the form of ellipsoids of revolution with an axial ratio of 1.0:1.6 in glass no. 4 (with the composition closest to the stoichiometric lithium disilicate composition), with an axial ratio of 1.0:2.0 in glass

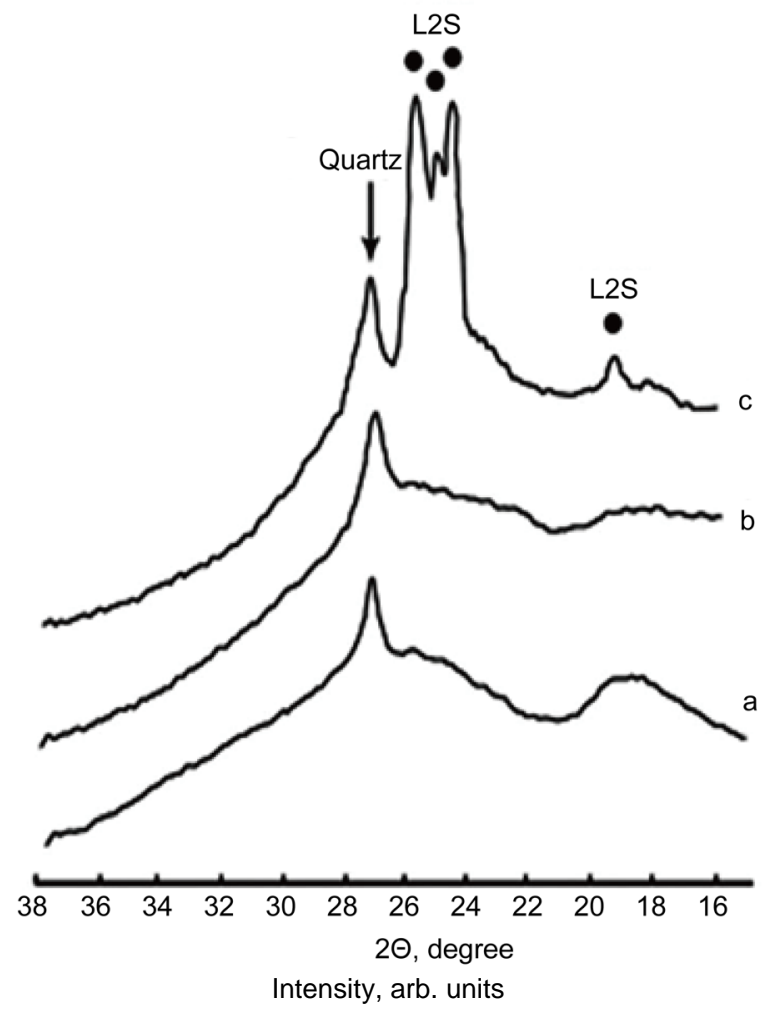

Figure 4. X-ray diffraction patterns of initial and heat treated glasses no. 2: (a) initial glass, (b) glass heat treated at $450^{\circ} \mathrm{C}$ for $5 \mathrm{~h}$, and (c) glass preliminarily heat treated at $450^{\circ} \mathrm{C}$ for $5 \mathrm{~h}$ and developed at $600^{\circ} \mathrm{C}$ for $10 \mathrm{~min}$. 


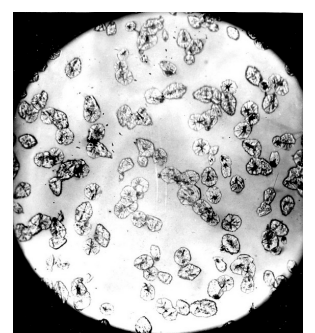

(a)

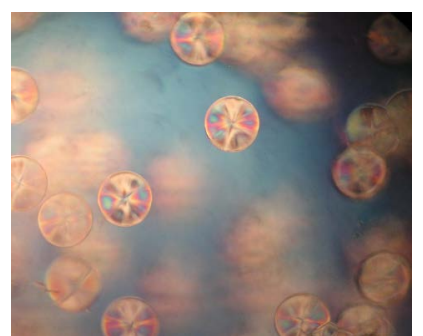

(b)

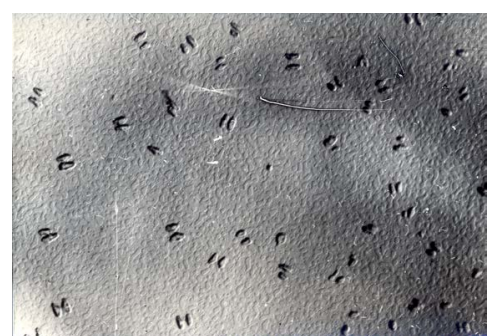

(c)

Figure 5. Shape of lithium disilicate crystals in: (a) glass no. 4 after preliminary heat treatment at the temperature $420^{\circ} \mathrm{C}$ for $4 \mathrm{~h}$; (b) glass no. 2 after preliminary heat treatment at the temperature $400^{\circ} \mathrm{C}$ for $4 \mathrm{~h}$; (c) glass no. 3 after heat treatment at the temperature $440^{\circ} \mathrm{C}$ for $8 \mathrm{~h}$. All samples were developed at the temperature $600^{\circ} \mathrm{C}$ for $10 \mathrm{~min}$. Image (a) was obtained in reflected light with the use of the Neophot 32 optical microscope at a magnification of 150. Image (b) was obtained in transmitted light with the use of the Jenaval optical microscope at a magnification of 200. Image (c) was obtained in reflected light with the use of an EM-125 transmission electron microscope at a magnification of 28000 .

no. 3 and in the shape of regular spheres in glass no. 2. The number of crystals increases with an increase in the holding time during preliminary heat treatment.

In order to nucleate lithium disilicate crystals, the samples of initial glasses no. 1 - no. 4 were held at temperatures in the range $420^{\circ} \mathrm{C}-520^{\circ} \mathrm{C}$ (range of the endothermic effect in the DTA curves). Then, the nucleated crystals were developed (to sizes visible in the optical microscope) at $600^{\circ} \mathrm{C}$ for $10 \mathrm{~min}$, i.e., at the temperature corresponding to the ascending branch of the exothermic peak in the DTA curve. The kinetics of homogeneous crystal nucleation was described using the stationary nucleation rate $I_{\mathrm{st}}$, nonstationary nucleation time $\tau$, and temperature dependences of these quantities.

\subsection{Determination of the Crystal Nucleation Rate}

The stationary nucleation rate $I_{\mathrm{st}}$ was determined from the experimental dependences of the number of crystals $n(t)$ as the slope of the stationary portion of these dependences on the holding time of glasses at each holding temperature. In this work, the rate of stationary homogeneous crystal nucleation was determined by the cross section method (in reflected light) and by direct counting of the number of crystals (in transmitted light). The glass samples were subjected to preliminary heat treatment and rapidly cooled in air to room temperature. Then, the samples were repeatedly heat treated at the development temperature of $600^{\circ} \mathrm{C}$ for $10 \mathrm{~min}$. With the aim of examining the samples in reflected light, the surface layer was ground off and the prepared surface was polished. In order to increase the contrast of the boundaries between crystals and glass, the sample surface was etched in a $0.01 M \mathrm{HF}$ solution for $10 \mathrm{~s}$. The number and size of cross sections of crystals per unit surface area were determined from the micrographs with the use of the Neophot optical microscope or directly in the field of vision of the Jenaval microscope.

The number of crystals per unit volume $n$ and the number of cross sections of crystals in the micro section $N_{S}$ are related by the expression $n=N_{S} /(S D)$, where $S$ is the 
micro section area and $D$ is the diameter of a maximum particle in the micro section. The nonstationary nucleation time $\tau$ was evaluated using the induction period $t_{\text {ind }}$, which differs from the time $\tau$ by the temperature independent factor.

The induction period $t_{\text {ind }}$ was determined as the intersection point between the continuation of the linear portion of the dependence $n(t)$ and the time axis. Then, we constructed the temperature dependences of all the aforementioned quantities.

\section{Experimental Results on Crystal Nucleation and Their Discussion}

The nucleation of the lithium disilicate was observed in all glasses. The dependences of the number of developed crystals $n$ in the nucleation temperature range $400^{\circ} \mathrm{C}-520^{\circ} \mathrm{C}$ (development at $600^{\circ} \mathrm{C}$ for $10 \mathrm{~min}$ ) were used to determine the stationary nucleation rate and the nonstationary nucleation time at each specific temperature. The induction period $t_{\text {ind }}$ decreases monotonically with an increase in the temperature. The temperature dependence of the induction period $t_{\text {ind }}(T)$ allows us to determine the activation energies for nucleation of lithium disilicate crystals $E_{\tau}$ from the formula $E_{\tau}=$ $R d \mathrm{n} t_{\text {ind }} / d(1 / T)$. The corresponding activation energies are equal to $129,128,127$ and $126 \mathrm{kcal} / \mathrm{mol}$ for glasses no. 1 - no. 4, respectively. The temperature dependences of the stationary nucleation rate of lithium disilicate crystals $I_{\mathrm{st}}(T)$ for the glass with the stoichiometric lithium disilicate composition and glasses with displaced compositions are shown in Figure 6. It can be seen from this figure that the nucleation rate of lithium disilicate crystals $I_{\mathrm{st}}\left(T_{\max }\right)$ at the maximum decreases from 160 to $60 \mathrm{~mm}^{-3} \cdot \mathrm{min}^{-1}$; in this case, the position of the maximum $T_{\max }$ is shifted toward higher temperatures by $12^{\circ} \mathrm{C}$. This relatively small change in the quantity $I_{\mathrm{st}}\left(T_{\max }\right)$ can be explained by the fact that the glasses with displaced compositions correspond to the phase separation region in the $\mathrm{Li}_{2} \mathrm{O}-\mathrm{SiO}_{2}$ system, so that the nucleation of the lithium disilicate occurs in phase separated inhomogeneities with the composition that is displaced toward the lithium disilicate composition and depends weakly on the temperature. The shift in the maximum $T_{\max }$ by $12^{\circ} \mathrm{C}$ can be explained by the increases in the viscosity and the glass transition temperature of the melt in the phase separated (matrix) region [106] [107] enriched by $\mathrm{SiO}_{2}$ as compared to the lithium disilicate composition, which provides an increase in the temperature $T_{\max }$ according to the relationship for the maximum of the nucleation rate

$$
T_{\max }=\frac{T_{\text {melt }}}{3} \frac{1+H_{A} / \Delta \Phi_{K}^{*}}{1+H_{A} / 3 \Phi_{K}^{*}}, \quad H_{A}=\Phi_{A}+T S_{A}, \quad S_{A}=-\frac{\partial \Phi_{A}}{\partial T},
$$

where $T_{\text {melt }}$ is the melting temperature and the enthalpy $H_{A}$, activation entropy $S_{A}$, and the nucleation barrier correspond to $T=T_{\max }$. It can be seen from Figure 6 that the temperature $T_{\max }$ of the maximum nucleation rate of lithium disilicate crystals for all the compositions under investigation is close to the glass transition temperature $T_{g}$. The closeness of the temperatures $T_{\max }$ and $T_{g}$ for the glass of the stoichiometric compositions and the glasses with displaced compositions can be explained as follows. The 


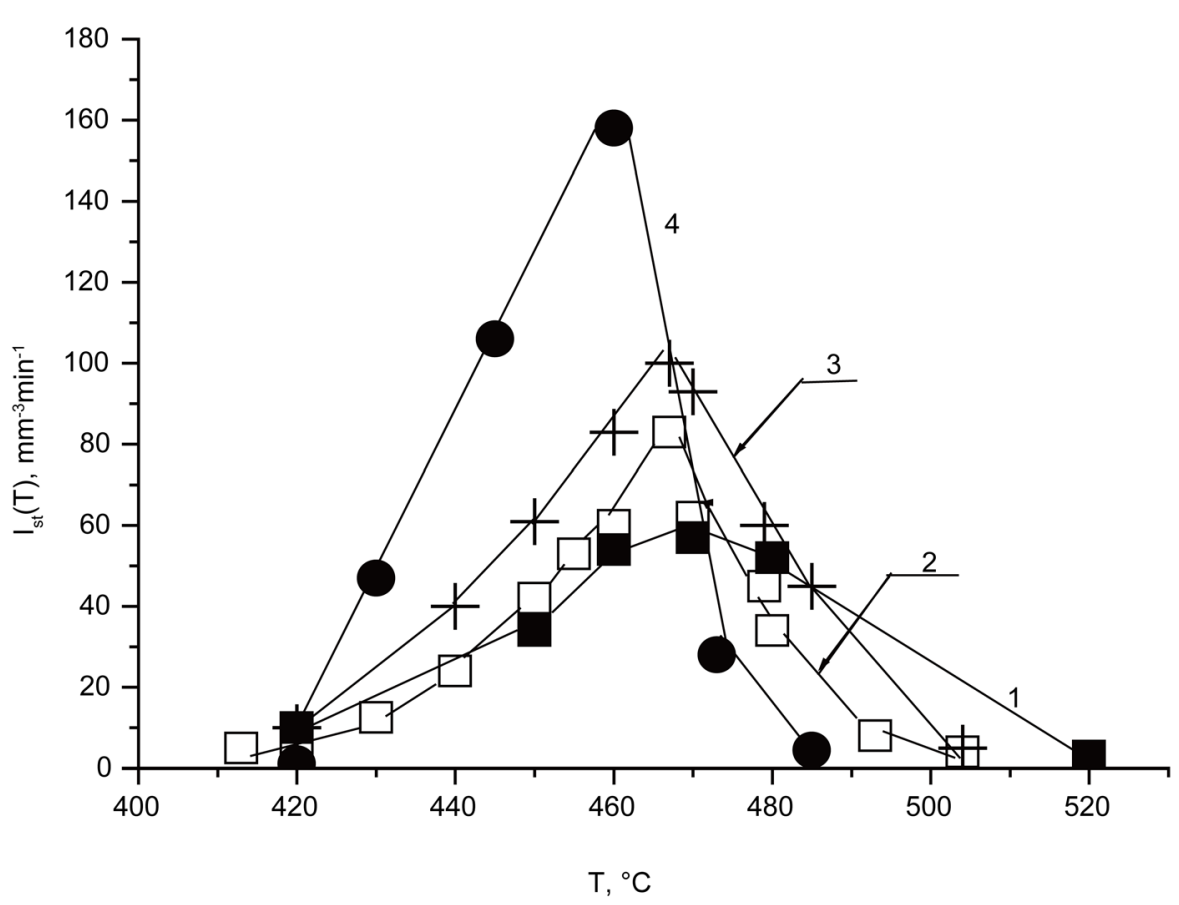

Figure 6. Temperature dependences of the stationary nucleation rate of lithium disilicate crystals $I_{\mathrm{st}}(T)$ for the glasses (1) no. 1, (2) no. 2 and (3) no. 3 with displaced compositions of the glasses and (4) with the stoichiometric lithium disilicate composition.

relative displacements of structural units that are necessary for crystal nucleation and occur through the breaking and switching of chemical bonds become sufficiently fast with an increase in the temperature beginning from the glass transition point $T_{g}$. The presence of the viscosity determined by the free activation energy $\Phi_{\eta}=\Phi_{A}$ leads to a shift in the maximum of the stationary nucleation rate $I_{\mathrm{st}}(T)$ according to relationship (6) toward higher temperatures ( $T_{\max }=T_{g}=2 / 3 T_{\text {melt }}$ ) as compared to its position $T_{\max }=$ $1 / 3 T_{\text {melt }}$ that would be observed at $H=0$.

\section{Crystal Growth Rate}

Before proceeding to the discussion of the results of the experiment on the determination of the growth rate of lithium disilicate crystals in glasses no. 1 - no. 3, let us consider the main notions used when determining the crystal growth. The crystal growth occurs as a result of accidental attachments and detachments of structural units from the surface of a supercritical nucleus (the supercritical nucleus is a nucleus with the size exceeding a critical size). The growth of the super-critical nucleus is thermodynamically favorable because this is accompanied by a decrease in the free energy of the system $\Delta \Phi$. The linear growth rate of the nucleus is determined by the equation

$$
U=\frac{\mathrm{d} r}{\mathrm{~d} t}=l\left(\beta_{+}-\beta_{-}\right),
$$

where $l$ is the thickness of the monomolecular layer growing on the crystal for some time interval, equal to the linear size of the structural unit), and $\beta_{+}$and $\beta_{-}$are the prob- 
abilities of attachment and detachment of one structural unit from the crystal surface per unit time:

$$
\beta_{+}=\frac{1}{\tau_{0}} \exp \left(-\frac{\Phi_{A}}{k T}\right), \quad \beta_{-}=\beta_{+} \exp \left[\frac{\left(\frac{\partial \Delta \Phi}{\partial a}\right)}{k T}\right]
$$

Here, $\tau_{0}$ is the time of the order of the period of vibrations of atoms in a chemical bond, whose switching provides the transition of the structural unit to the ordered state of the crystal structure of the nucleus; $\Delta \Phi$ is the change in the free energy of the system; and $a$ is the linear size of the structural unit. Substitution of these expressions into formula (7) gives

$$
U=\frac{1}{\tau_{0}} \exp \left(-\frac{\Phi_{A}}{k T}\right)\left\{1-\exp \left[-\frac{\Delta \varphi}{k T}\left(1-\frac{r^{*}}{r}\right)\right]\right\}
$$

where $\Delta \varphi$ is the difference between the free energies of the glass and nucleus per unit volume of the nucleus and $r^{\star}$ is the radius of the critical nucleus. It follows from this relationship that the growth rate of the critical nucleus is equal to zero. Since the critical nucleus is in an unstable equilibrium state, both the increase and decrease in its size is accompanied by a decrease in the difference $\Delta \varphi$ and is equally probable. With an increase in the size of the supercritical nucleus, the growth rate increases and becomes constant when the nucleus radius is larger than the critical radius $\left(r \gg r^{*}\right)$.

Now, we consider the temperature dependence of the stationary growth rate. Under the assumption that $\Delta \varphi \approx q\left(1-T / T_{\text {melt }}\right)$, where $q$ is the specific heat capacity, we have

$$
U(T) \approx \exp \left(-\frac{\Phi_{A}}{k T}\right)\left\{1-\exp \left[-\frac{q\left(1-T / T_{\text {melt }}\right)}{k T}\right]\right\}
$$

According to expression (10), the growth rate is equal to zero at $T \rightarrow 0$ and $T \rightarrow T_{\text {melt }}$. At some temperature $\left(0 \ll T_{\text {melt }}\right)$, the growth rate is maximum. This temperature can be evaluated. We assume that $\exp \left[-q\left(1-T / T_{\text {melt }}\right) / k T\right] \approx 1-q\left(1-T / T_{\text {melt }}\right) / k T$ and substitute into expression (10). After the differentiation with respect to the temperature, we obtain

$$
\frac{\mathrm{d} U}{\mathrm{~d} T} \approx \frac{1}{T^{2}} \exp \left(-\frac{\Phi_{A}}{k T}\right)\left[\frac{H_{A}}{k}\left(\frac{T_{\text {melt }}}{T}-1\right)-T_{\text {melt }}\right]
$$

From the extremum condition $\left.\left[\frac{H_{A}}{k}\left(\frac{T_{\text {melt }}}{T}-1\right)-T_{\text {melt }}\right]\right|_{T=T_{U_{m}}}=0$, we find that

$$
T_{U_{M}}=\frac{T_{\text {melt }}}{1+k T_{\text {melt }} / H_{A}}
$$

The quantity $k T_{\text {melt }} / H_{A}$ in formula (12) usually does not exceed $1 / 10$. Therefore, the temperature of the maximum growth rate is close to the melting temperature, and it is very difficult to experimentally determine this temperature. This inference is very im- 
portant for experimenters.

\section{Experimental Results on the Crystal Growth and Their Discussion}

\subsection{Crystal Growth Rate: Dependence on the Temperature}

There is a large number of works on the rate of crystal nucleation (see Table 1) in lithium silicate glasses, whereas investigations of the concentration dependences of the growth rate are absent. There exist works in which the results are presented only for specific compositions of glasses in this system [99] [108]. The photographs of characteristic lithium disilicate crystals grown at a development temperature of $600^{\circ} \mathrm{C}$ in glasses no. 1 - no. 3 are displayed in Figure 5. In order to determine the growth rate $U$, the dependences $R_{\max }(t)$ were constructed for a series of samples held for different times $t$ at a specified temperature. It was revealed that these dependences exhibit a linear behavior, which allows us to determine the crystal growth rate from their slope. In the case of spherical particles, their growth rate $U$ is determined from the expression $U=$ $\mathrm{d} R_{\max } / \mathrm{d} t^{\prime}$, where $t^{\prime}$ is the time of holding of the glass at the development temperature. In the case of ellipsoids of revolution, the growth rate $U$ is determined from the change in their average radius defined as the half sum of the major and minor radii of the ellipsoid. The crystal growth rates were studied at temperatures of $570^{\circ} \mathrm{C}, 590^{\circ} \mathrm{C}, 600^{\circ} \mathrm{C}$, $640^{\circ} \mathrm{C}, 685^{\circ} \mathrm{C}, 718^{\circ} \mathrm{C}, 720^{\circ} \mathrm{C}$, and $730^{\circ} \mathrm{C}$. The growth rates $U(T)$ of lithium disilicate crystals in glasses no. 1 - no. 4 as a function of the temperature are given in Table 4.

Figure 7 shows the temperature dependences of the growth rate $U$ for glasses no. 1 no. 3. The data presented in Figure 7(c) allow us to compare the growth rates $U$ determined in our work with those obtained in [109].

As can be seen from Figure 7(c), Burgner et al. [109] performed investigations at higher temperatures. We more thoroughly studied the growth rate at low temperatures. In the temperature range $575^{\circ} \mathrm{C}-600^{\circ} \mathrm{C}$, the results of both studies are in good agreement. It can be seen from Figure 7 that the growth rate $U(T)$ increases with an increase in the temperature. In the temperature range $640^{\circ} \mathrm{C}-718^{\circ} \mathrm{C}$, the growth rate increases linearly. It is difficult to judge the accurate position of the maximum of the growth rate $U(T)$, because the error in the measurement of the size at temperatures above $720^{\circ} \mathrm{C}$

Table 4. Growth rates $U(T)(\mu \mathrm{m} / \mathrm{min})$ of lithium disilicate crystals in glasses no. 1 - no. 4 as a function of the temperature.

\begin{tabular}{ccccccccccc}
\hline & \multicolumn{8}{c}{ Growth temperature, ${ }^{\circ} \mathrm{C}$} \\
Mlass no. & 570 & 590 & 600 & 640 & 685 & 700 & 718 & 720 & 730 \\
& & & \multicolumn{7}{c}{ Growth rate $U(T), \mu \mathrm{m} / \mathrm{min}$} \\
\hline 1 & 0.045 & 0.125 & 0.25 & 0.68 & 1.25 & - & 1.72 & 1.92 & 2.0 \\
2 & 0.036 & 0.125 & 0.31 & 0.44 & 1.12 & - & 1.66 & 1.58 & - \\
3 & 0.042 & 0.130 & 0.40 & 0.42 & 1.14 & 1.40 & 1.70 & 1.85 & - \\
4 & 0.225 & 0.625 & 1.25 & 3.4 & 6.25 & 8.6 & - & 10.0 & - \\
\hline
\end{tabular}




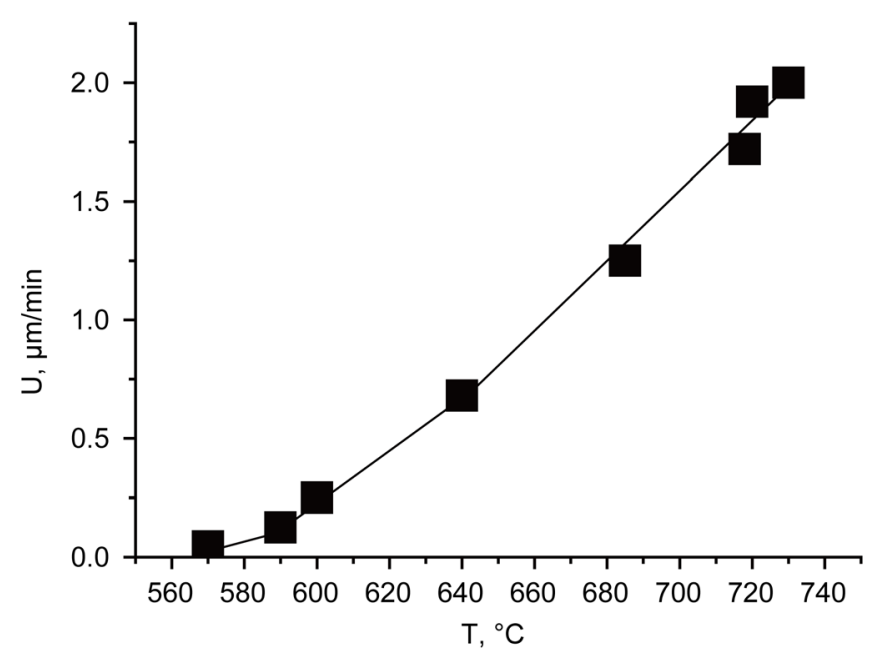

(a)

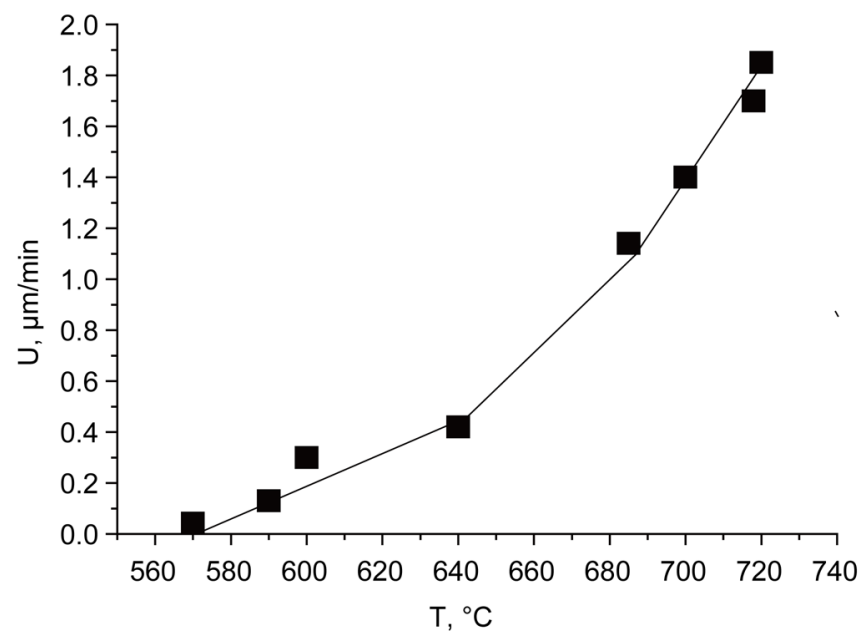

(c)

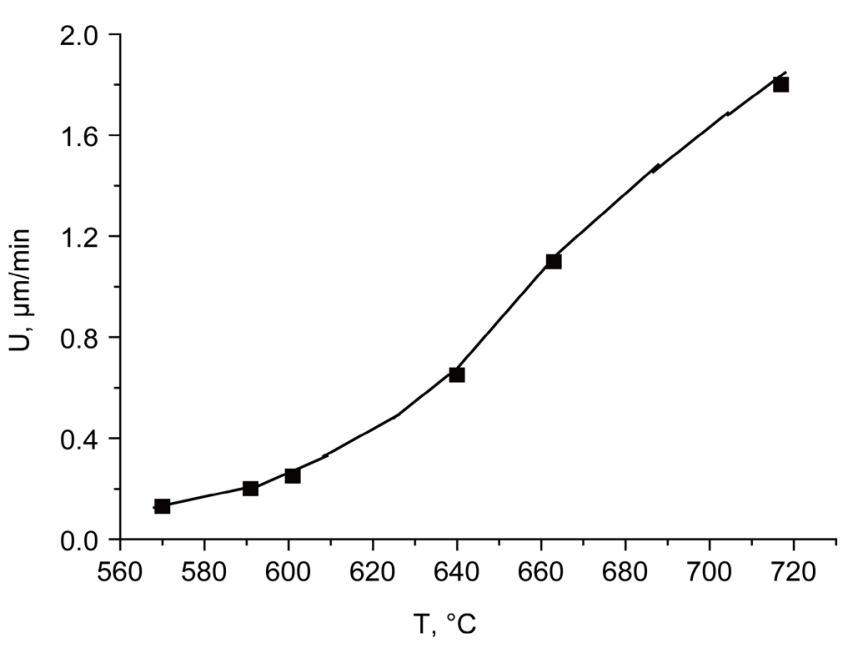

(b)

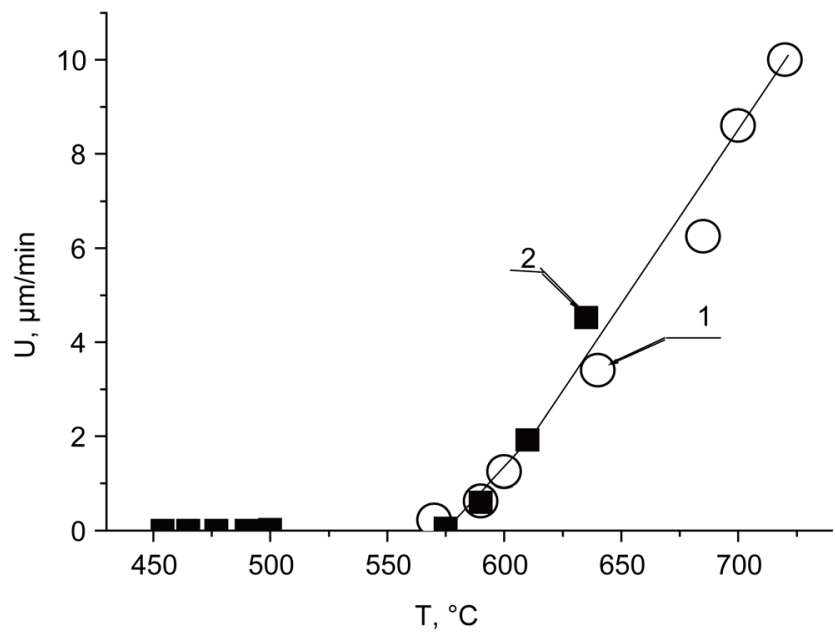

(d)

Figure 7. Temperature dependences of the growth rate $U$ for glasses (a) no. 1, (b) no. 2, (c) no. 3, and (d) no. 4 according to the data (1) obtained in this work and (2) taken from [109].

can increase in an uncontrollable manner due to the fact that the time of heat treatment of the sample ( $1-2 \mathrm{~min})$ is comparable to the time of its heating to a specified development temperature and we cannot state with assurance that crystals grew accurately at this temperature. Therefore, although the temperature dependence of the growth rate should have a maximum, we cannot argue that its true position is recorded. It is quite probable that the maximum of the growth rate is located at higher temperatures. The maxima of the nucleation rates are located at lower temperatures than the maxima of the growth rates. Theoretically, they can either be located at a large distance from each other or overlap. Since the accurate position of the maximum of the growth rate is not known, we can only to make the inference that, for the compositions under investigation, the positions of the temperature maxima of the nucleation and growth rates are spaced along the temperature scale by an uncertain value no less than $260^{\circ} \mathrm{C}\left(720^{\circ} \mathrm{C}\right.$ $460^{\circ} \mathrm{C}$ ). 


\subsection{Crystal Growth Rate: Dependence on the Time of Holding of the Glasses at the Temperature of $450^{\circ} \mathrm{C}$}

The growth rates of lithium disilicate crystals as a function of the holding time glasses at a constant temperature were investigated at the temperature of $450^{\circ} \mathrm{C}$. The results of the measurements are presented in Figure 8.

It can be seen from this figure that the dependence of the growth rate of lithium disilicate crystals in glasses no. 1 , no. 2 and no. 3 on the time of low-temperature heat treatment exhibit an oscillatory behavior with a gradual decay of the oscillation amplitude and a retardation of the growth process. In the framework of the existing theories of nucleation and growth, it was demonstrated for metal alloys [110] that the retardation of the growth process is caused simultaneously by nucleation, growth, and dissolution of particles. For glass no. 4 (with the stoichiometric lithium disilicate composition),

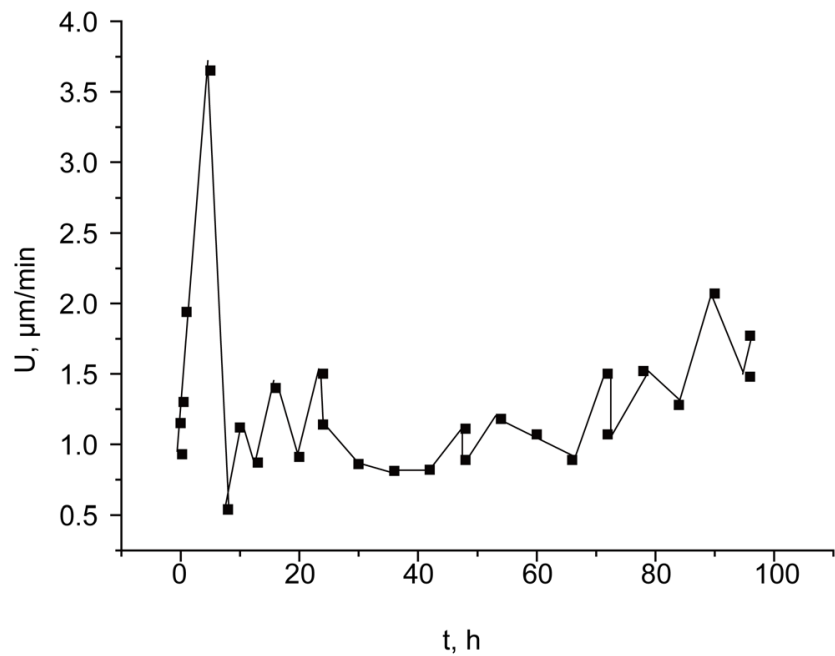

(a)

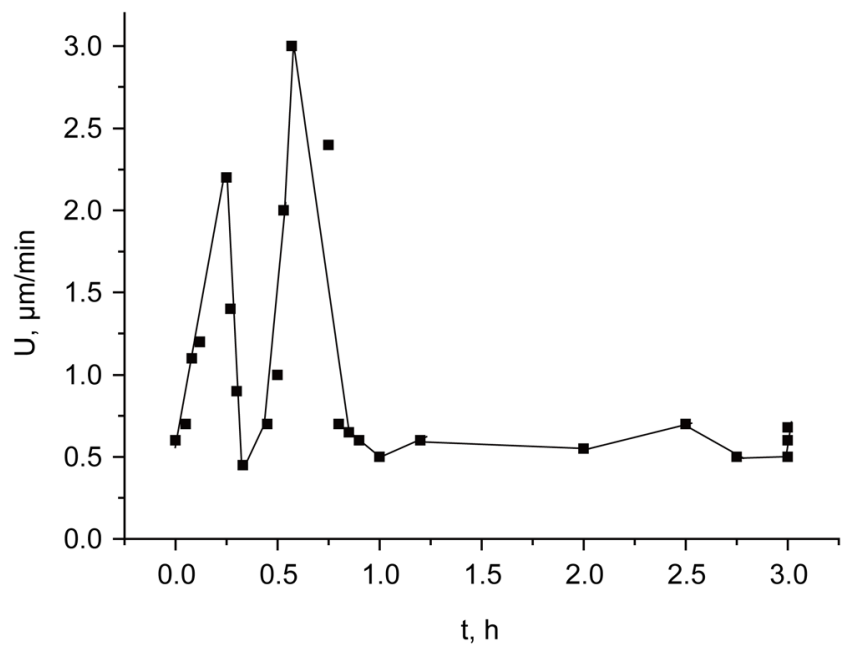

(c)

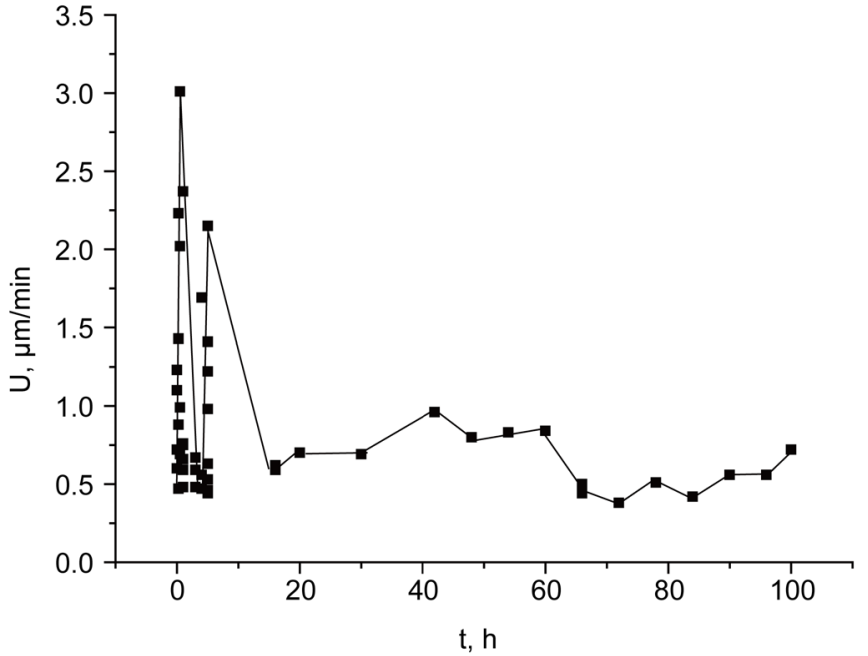

(b)

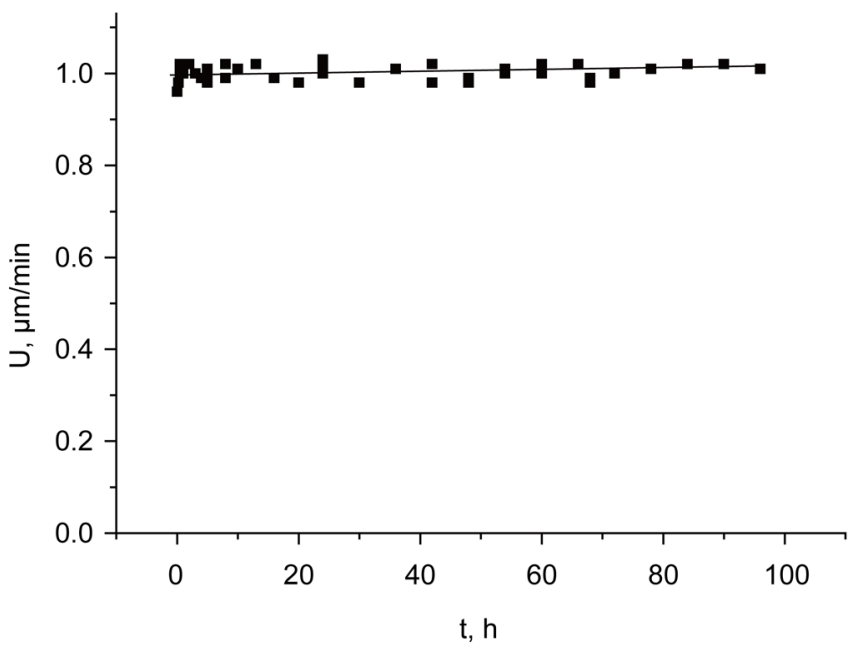

(d)

Figure 8. Dependences of the growth rate $U$ on the time of heat treatment at $450^{\circ} \mathrm{C}$ for glasses (a) no. 1, (b) no. 2 , (c) no. 3 and (d) no. 4 . Samples were developed at the temperature of $600^{\circ} \mathrm{C}$ for $10 \mathrm{~min}$. 
the crystal growth rate does not depend on the time of low-temperature heat treatment (Figure 8(c)).

The gradual decrease in the crystal growth rate with an increase in the time of holding of the glass at a temperature of $450^{\circ} \mathrm{C}$ for glasses no. 1, no. 2 and no. 3 (Figures $8(a)-8(c))$ can be explained by the fact that the crystals grow in the glass with the composition lying in the metastable phase separation region. A part of the material is spent for forming the crystal layer, and the growing crystal appears to be surrounded by the region depleted in the building material (the so-called diffusion zone) (Figure 9). The formation of the next crystal layer requires the time it takes for phase separated droplets to come to the crystal growth region. In this case, the phase separated droplets consist predominantly of $\mathrm{SiO}_{2}$.

When the droplets come closer to the growing lithium disilicate crystal, they will block its growth, which manifests itself in the dependences (Figures $8(a)-8(c)$ ) as a decrease in the crystal growth rate.

\section{Conclusions}

Thus, we have investigated the kinetics of phase separation in three lithium silicate glasses containing $23.4,26.0$ and $29.1 \mathrm{~mol} \% \mathrm{Li}_{2} \mathrm{O}$ with the compositions lying in the phase separation region in the $\mathrm{Li}_{2} \mathrm{O}-\mathrm{SiO}_{2}$ system. It has been found that the temperature dependences of the ratio of the number of traces to the maximum number of traces $N_{S} / N_{S \max }$ and the ratio of the radius of the particle trace to the maximum radius $R / R_{\max }$ exhibit maxima. The crystal nucleation rate has been studied in glasses with the compositions displaced from the stoichiometric lithium disilicate composition toward an increase in the $\mathrm{SiO}_{2}$ content. The following features have been revealed.

1) The absolute values of the crystal nucleation rate in glasses with the lower content $\mathrm{Li}_{2} \mathrm{O}$ than that in the glass with the stoichiometric lithium disilicate composition vary insignificantly.

2) The position of the temperature maximum of the nucleation rate for the glass with the lower lithium oxide content is shifted on the temperature scale by $12^{\circ} \mathrm{C}$. This relatively small change in the quantities $I_{s t}\left(T_{\max }\right)$ and $T_{\max }$ is explained by the fact that the glasses with the displaced composition correspond to the phase separation region in

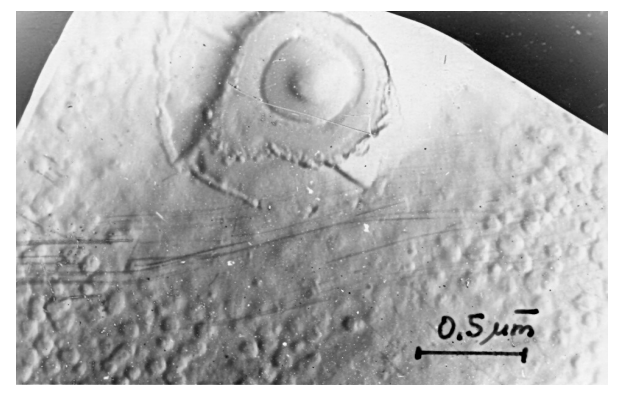

(a)

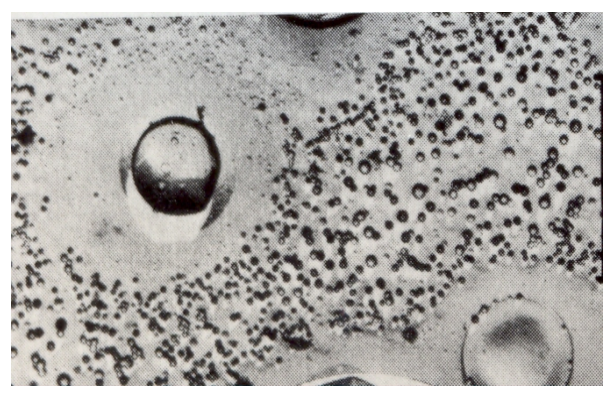

(b)

Figure 9. Electron microscopic images of glasses (a) no. 1 and (b) no. 2 preliminarily heat treated at the temperature of $440^{\circ} \mathrm{C}$ for $2 \mathrm{~h}$ and developed at $600^{\circ} \mathrm{C}$ for $10 \mathrm{~min}$. 
the $\mathrm{Li}_{2} \mathrm{O}-\mathrm{SiO}_{2}$ system, so that the lithium disilicate in glasses with displaced composition nucleates in phase separated inhomogeneities with compositions that are displaced toward the lithium disilicate composition and depend weakly on the temperature.

Variations in the crystal growth rate have been investigated as a function of the temperature and time of heat treatment. It has been shown that the temperature dependences of the crystal growth rate tend to an extremum. It has been found that the crystal growth rate depends substantially on the heat treatment time for phase separated glasses and that the growth rate is constant for the glass with the stoichiometric lithium disilicate composition. The dependence of the crystal growth rate on the heat treatment time in phase separated glasses exhibits a damped oscillatory behavior, which is explained by the depletion of the building material for crystals and the necessity of some time for its supply. Therefore, the performed investigations allow us to draw the following conclusion. Unlike the universally accepted opinion, the phase separation not only does not facilitate the conditions for the formation and growth of crystals but, in some cases (see, for example, the dependences of the crystal growth rate on the time of low-temperature heat treatment), even retards the crystal growth process. The data obtained on the nucleation and growth of crystals help to find optimum compositions and temperature-time conditions for the preparation of many glass-ceramic nanomaterials in lithium silicate system, including photostructured materials.

\section{References}

[1] Liebau, F. (1961) Untersuchungen an Schichtsilicaten des Formeltypes $\mathrm{A}_{\mathrm{m}}\left(\mathrm{Si}_{2} \mathrm{O}_{5}\right)_{\mathrm{n}}$. I. Die Kristallstructur der Zimmertemperaturform des $\mathrm{Li}_{2} \mathrm{Si}_{2} \mathrm{O}_{5}$. Acta Crystallographica, 14, 389395. http://dx.doi.org/10.1107/S0365110X61001303

[2] Jaccodine, R.J. (1961) Study of Devitrification of Lithium Glass. Journal of the American Ceramic Society, 44, 8-11. http://dx.doi.org/10.1111/j.1151-2916.1961.tb13708.x

[3] Kalinina, A.M., Filipovich, V.N., Kolesova, V.A. and Bondar I.A. (1963) On the Products of Crystallization of Lithium Silicate Glasses. In: Stekla, M.-L., Ed., The Vitreous State. Vyp.1. Katalizirovannaya kristallizatsiya Stekla (pp. 53-66). M.-L.: Izv. Akad. Nauk SSSR. (In Russian)

[4] Glasser, F.P. (1967) Crystallisation of Lithium Disilicate from $\mathrm{Li}_{2} \mathrm{O}-\mathrm{SiO}_{2}$ Glasses. Physics and Chemistry of Glasses, 8, 224-232.

[5] Ito, M., Sacaino, T. and Moriya, T. (1968) Study on the Process of Crystallization of the $\mathrm{Li}_{2} \mathrm{O}_{2} \mathrm{SiO}_{2}$ Glass. I. Rates of Crystal Growth and Nucleation. Bulletin of the Tokyo Institute of Technology, 127-149.

[6] Ito, M., Sacaino, T. and Moriya, T. (1968) Study on the Process of Crystallization of the $\mathrm{Li}_{2} \mathrm{O}_{2} \mathrm{SiO}_{2}$ glass I Variation of Electric Properties with Crystallization. Bulletin of the Tokyo Institute of Technology, 151-171.

[7] Filipovich, V.N. and Kalinina, A.M. (1968) On the Nature of the Influence of Heat Treatment on the Crystallization Kinetics of Lithium Silicate Glasses. Izvesttiya Akademii Nauk SSSR Neorganicheskie Materialy, 4, 1532-1538. (In Russian)

[8] Kinser, D.L. and Hench, L.L. (1968) Effect of a Metastable Precipitate on the Electrical Properties of an $\mathrm{Li}_{2} \mathrm{O}-\mathrm{SiO}_{2}$ Glass. Journal of the American Ceramic Society, 51, 445-448. http://dx.doi.org/10.1111/j.1151-2916.1968.tb11916.x 
[9] Ogura, T., Hayami, R. and Kadota, M. (1968) Kinetics and Mechanism of Crystallization of Lithium Silicate Glasses. Journal of the Ceramic Association, 76, 277-284. http://dx.doi.org/10.2109/jcersj1950.76.876 277

[10] Freiman, S.W. and Hench, L.L. (1968) Kinetics of Crystallization in $\mathrm{Li}_{2} \mathrm{O}-\mathrm{SiO}_{2}$ Glasses. Journal of the American Ceramic Society, 51, 382-387. http://dx.doi.org/10.1111/j.1151-2916.1968.tb11898.x

[11] Kashchiev, D. (1969) Solution of the Non-Steady State Problem in Nucleation Kinetics. Surface Science, 14, 209-220. http://dx.doi.org/10.1016/0039-6028(69)90055-7

[12] Filipovich, V.N. and Kalinina, A.M. (1970) Crystallization Kinetics of Lithium Disilicate from Simple and Complex Glasses. Izvesttiya Akademii Nauk SSSR Neorganicheskie Materialy, 6, 351-356. (In Russian)

[13] Kalinina, A.M. (1970) On the Polymorphism of Lithium Disilicate. Izvesttiya Akademii Nauk SSSR Neorganicheskie Materialy, 6, 907-913. (In Russian)

[14] Hench, L.L., Frieman, S.W. and Kinser, D.L. (1971) The Early Stages of Crystallization in $\mathrm{Li}_{2} \mathrm{O}-2 \mathrm{SiO}_{2}$ Glass. Physics and Chemistry of Glasses, 12, 58-63.

[15] Sycheva, G.A. (1972) Temperature Dependence of the Nucleation Rate of Crystals in Some Silicate Glasses/Brief Abstracts of the Conference of Young Specialists. Institute of Silicate Chemistry Behalf I.V. Grebenshchikova, Leningrad, 15-16. (In Russian)

[16] Matusita, K. and Tashiro, M. (1973) Rate of Homogeneous Nucleation in Alkali Disilicate Glasses. Journal of Non-Crystalline Solids, 11, 471-484.

http://dx.doi.org/10.1016/0022-3093(73)90092-6

[17] James, P.F. and Keown, S.R. (1974) Study of Crystallization in Lithium Silicate Glasses Using High-Voltage Microscopy. Philosophical Magazine, 30, 789-802.

http://dx.doi.org/10.1080/14786437408207235

[18] James, P.F. (1974) Kinetics of Crystal Nucleation in Lithium Silicate Glasses. Physics and Chemistry of Glasses, 15, 95-105.

[19] Kalinina, A.M., Fokin, V.M. and Filipovich, V.N. (1976) On the Method of Determining the Parameters Characterizing the Crystal Nucleation in Glasses. Fizika i Khimiya Stekla, 2, 298-305. (In Russian)

[20] Kalinina, A.M., Fokin, V.M. and Filipovich, V.N. (1977) Induction Period of Crystal Nucleation in $\mathrm{Li}_{2} \mathrm{O} \cdot 2 \mathrm{SiO}_{2}$ Glass and Its Temperature Dependence. Fizika i Khimiya Stekla, 3, 122-129. (In Russian)

[21] Fokin, V.M., Filipovich, V.N. and Kalinina, A.M. (1977) The Effect of Preliminary Heat Treatment on Crystal Nucleation in $\mathrm{Li}_{2} \mathrm{O}-2 \mathrm{SiO}_{2}$ Glass. Fizika i Khimiya Stekla, 3, 129-136. (In Russian)

[22] James, P.F., Scott, B. and Armstrong, P. (1978) Kinetics of Crystal Nucleation in Lithium Disilicate Glass. A Comparison between Melts Prepared in Platinum and Silica Crucibles and between Melts Prepared from Ordinary and High Purity Starting Materials. Physics and Chemistry of Glasses, 19, 24-27.

[23] Rowlands, E.G. and James, P.F. (1979) Analysis of Steady State Crystal Nucleation Rates in Glasses. Part 1. Methods of Analysis and Application to Lithium Disilicate Glass. Physics and Chemistry of Glasses, 20, 1-8.

[24] Rowlands, E.G. and James, P.F. (1979) Analysis of Steady State Crystal Nucleation Rates in Glasses. Part 2. Further Comparison between Theory and Experiment for Lithium Disilicate Glass. Physics and Chemistry of Glasses, 20, 9-14.

[25] Matusita, K. and Sakka, S. (1979) Kinetic Study of the Crystallisation of Glass by Differen- 
tial Scanning Calorimetry. Physics and Chemistry of Glasses, 20, 81-84.

[26] Ghoneim, N.A., El Batal, H.A., Ahmed, A.A. and Khalifa, F.A. (1979) Crystallization of Lithium Trisilicate Glasses. Transactions and journal of the British Ceramic Society, 78, 1522 .

[27] Gonzalez-Oliver, C.J.R., Johnson, P.S. and James, P.F. (1979) Influence of Water Content on the Rates of Crystal Nucleation and Growth in Lithia-Silicate and Soda-Lime-Silica Glasses. Journal of Materials Science, 14, 1159-1169. http://dx.doi.org/10.1007/BF00561300

[28] Fokin, V.M., Kalinina, A.M. and Filipovich, V.N. (1981) Nucleation in Silicate Glasses and Effect of Preliminary Heat Treatment on It. Journal of Crystal Growth, 52, 115-121. http://dx.doi.org/10.1016/0022-0248(81)90178-0

[29] Marotta, A., Buri, A., Branda, F. and Saiello, S. (1982) Nucleation and Crystallization of $\mathrm{Li}_{2} \mathrm{O} \cdot 2 \mathrm{SiO}_{2}-\mathrm{A}$ DTA Study. In: Simmons, J.H., Uhlmann, D.R. and Beall, G.H., Eds., $A d-$ vances in Ceramics, Nucleation and Crystallization in Glasses, Vol. 4, American Ceramic Society, Columbus, 146-152.

[30] Kalinina, A.M., Sycheva, G.A. and Filipovich, V.N. (1983) Homogeneous and Heterogeneous Crystal Nucleation in Some Silicate Glasses. Glastehnische Berichte, 2, 816-821.

[31] Huang, Z.J., Yoko, T., Kamiya, K. and Sakka, S. (1983) Effect of Water on the Crystallization of $\mathrm{Li}_{2} \mathrm{O}_{-} \mathrm{SiO}_{2}$ Glasses and Gels. Yogyo-Kyokai-Shi, 91, 215-221. (In Japanese) http://dx.doi.org/10.2109/jcersj1950.91.1053 215

[32] Zanotto, E.D. and James, P.F. (1985) Experimental Test of the Classical Nucleation Theory for Glasses. Journal of Non-Crystalline Solids, 74, 373-394.

http://dx.doi.org/10.1016/0022-3093(85)90080-8

[33] Sycheva, G.A., Kalinina, A.M. and Filipovich, V.N. (1986) Change of Nucleation Kinetic of Lithium Di-and Metasilicate Crystals in Photosensitive Glasses at Transition from Heterogeneous to Homogeneous Nucleation. Fizika i Khimiya Stekla, 11, 123-125. (In Russian)

[34] Kalinina, A.M., Sycheva, G.A., Filipovich, V.N., et al. (1986) Auto-Catalytic Nucleation of Lithium Silicate Glasses. Fizika i Khimiya Stekla, 12, 260-264. (In Russian)

[35] Kalinina, A.M., Fokin, V.M., Sycheva, G.A. and Filipovich, V.N. (1986) Three Types of Catalysis of Lithium Disilicate Crystal Nucleation in Lithium Silicate Glasses. Proceedings of the 14th International Congress on Glass, 1, 366-373.

[36] Kalinina, A.M., Sycheva, G.A. and Filipovich, V.N. (1986) Catalyzed and Spontaneous Nucleation of Lithium Disilicate Crystals in Nonphotosensitive and Photosensitive Glasses, in Katalizirovannaya kristallizatsiya Stekla. In: Hodakovskaya, R.Ya., Ed., Trudy Gosudarstvennogo Instituta Stekla (Catalyzed Crystallization of a Glass. Transactions of the State Institute of Glass), Gos. Inst. Stecla, Moscow, 56-59. (In Russian)

[37] Hishinuma, A. and Uhlman, D.R. (1987) Nucleation Kinetics in Some Silicate GlassForming Melts. Journal of Non-Crystalline Solids, 95-96, 449-456. http://dx.doi.org/10.1016/S0022-3093(87)80143-6

[38] Braetsh, V. and Frischat, G.H. (1987) Crystallization and Phase Separation in the System $\mathrm{Li}_{2} \mathrm{O}-\mathrm{SiO}_{2}$. Journal of Non-Crystalline Solids, 95-96, 457-464. http://dx.doi.org/10.1016/S0022-3093(87)80144-8

[39] Market, M.F., Wang, T.H. and James, P.F. (1988) Nucleation and Growth Kinetics of Lithium Disilicate and Lithium Metasilicate in Lithia-Silica Glasses. Physics and Chemistry of Glasses, 29, 240-248.

[40] Filipovich, V.N., Kalinina, A.M. and Sycheva, G.A. (1988) Glass Formation and Catalyzed Crystal Nucleation. Trudy 8 th Vsesoyuznogo soveshchaniya po stekloobraznomu sostoyaniyu [Proceeding of 8th All-Union Conference on the Vitreous State], Leningrad, 28-31 
October 1986, 87-96. (In Russian)

[41] Schlesinger, M.E. and Lynch, D.C. (1989) Effect of VB and VIB Oxides on Nucleation Parameters in Lithium Disilicate Glass. Journal of Non-Crystalline Solids, 108, 237-248. http://dx.doi.org/10.1016/0022-3093(89)90294-9

[42] Sycheva, G.A., Kalinina, A.M. and Filipovich, V.N. (1989) Transition Kinetic from the Heterogeneous to the Homogeneous Nucleation in Some Silicate Glasses. In: Glass and Fine Ceramics, Varna, 18-20 September 1987: Proceedings of 9 th National Scientific Conference with International Participation, Sophia, 239-245.

[43] Ray, C.S. and Day, D.E. (1990) Determining the Nucleation Rate Curve for Lithium Disilicate Glass by Differential Thermal Analysis. Journal of the American Ceramic Society, 73. 439-442. http://dx.doi.org/10.1111/j.1151-2916.1990.tb06532.x

[44] Boiko, G.G., Sycheva, G.A. and Valjuk, L.G. (1990) Influence of Synthesis Conditions of Photosensitive Glass on Its Crystallization Kinetics. In: Glass and Fine Ceramics, Varna, 18-20 October 1990: Proceedings of 10 th National Scientific Conference with International Participation, 1, 282.

[45] Kalinina, A.M., Filipovich, V.N. and Sycheva, G.A. (1991) The Mutual Influence of Crystal Nucleation in Complex Glasses. In: Hodakovskaya, R.Ya., Ed., Amorfno-kristallicheskie materially. Sintez, struktura, svoistva, primenenie. Sbornik trudov MKhTI im [AmorphousCrystalline Materials. Synthesis, Structure, Properties, and Applications. A Collection of Articles of the Mendeleev University of Chemical Technology], Mendeleev University of Chemical Technology, Moscow, 77-85. (In Russian)

[46] Deubener, J., Bruckner, R. and Sterenitzke, M. (1993) Induction Time Analysis of Nucleation and Crystal Growth in Di- and Metasilicate Glasses. Journal of Non-Crystalline Solids, 163, 1-12. http://dx.doi.org/10.1016/0022-3093(93)90638-E

[47] Boiko, G.G., Sycheva, G.A. and Valjuk, L.G. (1995) Influence of Synthesis Conditions on the Kinetics of Crystallization of Photosensitive Lithium Silicate Glasses. Fizika i Khimiya Stekla, 21, 45-52. (In Russian)

[48] Davis, M.J. (1996) Influence of Water and Thermal History on Viscosity and Nucleation Kinetics of Lithium Disilicate Melt. Geology and Geophysics, Yale University, New Haven, 159.

[49] Sycheva, G.A. (1996) Transition from the Heterogeneous to the Homogeneous Nucleation in Some Silicate and Phosphate Glasses. Proceedings of the International Symposium on Glass Problems, 2, 373-379.

[50] Mishima, N., Ota, R., Wakasugi, T. and Fukunaga, J. (1996) Analysis of Crystallization Behavior in $\mathrm{Li}_{2} \mathrm{O} 2 \mathrm{SiO}_{2}$ Glass by DTA Method Based on a Liquid Model. Journal of NonCrystalline Solids, 197, 19-24. http://dx.doi.org/10.1016/0022-3093(95)00570-6

[51] Narayan, K.L., Kelton, K.F. and Ray, C.S. (1996) Effect of Pt Doping on Nucleation and Crystallization in $\mathrm{Li}_{2} \mathrm{O} 2 \mathrm{SiO}_{2}$ Glass: Experimental Measurements and Computer Modeling. Journal of Non-Crystalline Solids, 195, 148-157. http://dx.doi.org/10.1016/0022-3093(95)00526-9

[52] Zanotto, E.D. and Gomes Leite, M.L. (1996) The Nucleation Mechanism of Lithium Disilicate Glass Revisited. Journal of Non-Crystalline Solids, 202, 145-151. http://dx.doi.org/10.1016/0022-3093(96)00187-1

[53] Davis, M.J., Ihinger, P.D. and Lasaga, A.C. (1997) Influence of Water on Nucleation Kinetics in Silicate Melt. Journal of Non-Crystalline Solids, 219, 62-69. http://dx.doi.org/10.1016/S0022-3093(97)00252-4

[54] Kalinina, A.M., Filipovich, V.N. and Sycheva, G.A. (1997) Heterogeneous Nucleation in 
Photosensitive Glasses. Journal of Non-Crystalline Solids, 219, 80-83.

http://dx.doi.org/10.1016/S0022-3093(97)00255-X

[55] Holland, D., Iqbal, Y., James, P. and Lee, B. (1998) Early Stages of Crystallization of Lithium Disilicate Glasses Containing $\mathrm{P}_{2} \mathrm{O}_{5}-\mathrm{An}$ NMR Study. Journal of Non-Crystalline Solids, 232-234, 140-146. http://dx.doi.org/10.1016/S0022-3093(98)00381-0

[56] Sycheva G.A. (2015) Determination of the Size of the Critical Nucleus of Crystals in Lithium and Sodium Silicate Glass. Glass Physics and Chemistry, 41, 302-306. http://dx.doi.org/10.1134/S1087659615030165

[57] Iqbal, Y., Lee, B., Holland, D. and James, P. (1998) Metastable Phase formation in the Early Stage Crystallization of the Lithium Disilicate Glass. Journal of Non-Crystalline Solids, 224, 1-16. http://dx.doi.org/10.1016/S0022-3093(97)00453-5

[58] Hasdemir, I., Bruckner, R., Deubener, J. (1998) Crystallization of Lithium Di- and Metasilicate Solid Solutions from $\mathrm{Li}_{2} \mathrm{O}-\mathrm{SiO}_{2}$ Glasses. Physics and Chemistry of Glasses, 39, 253 257.

[59] Davis, M.J. and Ihinger, P.D. (1998) Heterogeneous Crystal Nucleation on Bubbles in Silicate Melt. American Mineralogist, 83, 1008-1015. http://dx.doi.org/10.2138/am-1998-9-1008

[60] Davis M.J. and Ihinger P.D. (1999) Influence of Hydroxyl on Glass Transformation Kinetics in Lithium Disilicate Melt and a Re-Evaluation of Structural Relaxation in NBS 710 and 711. Journal of Non-Crystalline Solids, 244, 1-15. http://dx.doi.org/10.1016/S0022-3093(98)00844-8

[61] Burgner, L.L., Weinberg, M.C., Lucas, P., Soares Jr., P.C., Zanotto, E.D. (1999) XRD Investigation of Metastable Phase Formation in $\mathrm{Li}_{2} \mathrm{O}-\mathrm{SiO}_{2}$ Glasses. Journal of Non-Crystalline Solids, 255, 264-268. http://dx.doi.org/10.1016/S0022-3093(99)00376-2

[62] Burgner, L.I., Lucas, P., Weinberg, M.C., Soares Jr., P.C. and Zanotto, E. (2000) D. Metastable Phase Formation in the Early Stage Crystallisation of Lithium Disilicate Glass. Journal of Non-Crystalline Solids, 274, 188-194. http://dx.doi.org/10.1016/S0022-3093(00)00187-3

[63] Kitamua, N., Fukumi, K., Mizoguchi, H., Makihara, M., Higuchi, A., Ohno, N. and Fukunaga, T. (2000) High Pressure Densification of Lithium Silicate Glasses. Journal of Non-Crystalline Solids, 274, 244-248. http://dx.doi.org/10.1016/S0022-3093(00)00190-3

[64] Kanert, O., Kuchler, R., Suter, D., Shannon, G.N. and Jain, H. (2000) Effect of Devitrification on the Ionic Diffusion of Li-Disilicate. Journal of Non-Crystalline Solids, 274, 202-207. http://dx.doi.org/10.1016/S0022-3093(00)00189-7

[65] Burgner, L.L. and Weinberg, M.C. (2001) Crystal Growth Mechanisms in Inorganic Glasses. Physics and Chemistry of Glasses, 42, 184-190.

[66] Burgner, L.L. and Weinberg M.C. (2001) An Assessment of Crystal Growth Behavior in Lithium Disilicate Glass. Journal of Non-Crystalline Solids, 279, 28-43.

http://dx.doi.org/10.1016/S0022-3093(00)00325-2

[67] Soares Jr., P.C., Zanotto, E.D., Fokin, V.M., Jain, H.J. and Weinberg, M.C. (2003) TEM and XRD Srudy of Early Crystallization of Lithium Disilicate Glasses. Journal of Non-Crystalline Solids, 331, 217-227. http://dx.doi.org/10.1016/j.jnoncrysol.2003.08.075

[68] Filipovich, V.N. and Kalinina, A.M. (1971) On the Relation between the Maximum of the Crystal Nucleation Rate in Glasses and the Glass Transition Temperature, Izvesttiya Akademii Nauk SSSR Neorganicheskie Materialy, 7, 1844-1848.

[69] Gonzalez-Oliver, C.J.R. (1979) Crystal Nucleation and Growth in Soda-Lime-Silica Glasses. PhD Thesis, the University of Sheffield, Sheffield, $175 \mathrm{p}$. 
[70] Gonzalez-Oliver, C.J.R. and James, P.F. (1980) Crystal Nucleation and Growth in a $\mathrm{Na}_{2} \mathrm{O} .2 \mathrm{CaO} .3 \mathrm{SiO}_{2}$ Glass. Journal of Non-Crystalline Solids, 38-39, 699-704.

http://dx.doi.org/10.1016/0022-3093(80)90518-9

[71] Kalinina, A.M., Filipovich, V.N. and Fokin V.M. (1980) Stationary and Non-Stationary Crystal Nucleation Rates in the $\mathrm{Na}_{2} \mathrm{O} \cdot 2 \mathrm{CaO} .3 \mathrm{SiO}_{2}$ Glass of Stoichiometric Composition. Journal of Non-Crystalline Solids, 38-39, 723-728.

http://dx.doi.org/10.1016/0022-3093(80)90522-0

[72] James, P.F. (1982) Nucleation in Glass-Forming Systems-A Review. In: Simmons, J.H. and Beau, G.H., Eds., Nucleation and Crystallization in Glasses Vol. 4: Advances in Ceramics, American Ceramic Society, Columbus, 1-48.

[73] Ramsden, A.H. and James, P.F. (1984) The Effect of Amorphous Phase Separation on Crystal Nucleation Kinetics in $\mathrm{BaO}-\mathrm{SiO}_{2}$ Glasses. Part 1. General Survey. Journal of Materials Science, 19, 1406-1419. http://dx.doi.org/10.1007/BF00563035

[74] Ramsden A.H. and James, P.F. (1984) The Effect of Amorphous Phase Separation on Crystal Nucleation Kinetics in $\mathrm{BaO}-\mathrm{SiO}_{2}$ Glasses. Part 2. Isothermal Heat Treatments at $700^{\circ} \mathrm{C}$. Journal of Materials Science, 19, 2894-2908. http://dx.doi.org/10.1007/BF01026965

[75] James, P.F. (1993) Experimental Studies of Crystal Nucleation in Glasses. In: Weinberg, M.C., Ed., Nucleation and Crystallization in Liquids and Glasses Vol. 30: Ceramic Transactions, American Ceramic Society, Westerville, 3-12.

[76] Gránásy, L., Wang, T. and James, P.F. (1998) Kinetics of Wollastonite Nucleation in $\mathrm{CaO} \cdot \mathrm{SiO}_{2}$ Glass. Journal of Chemical Physics, 108, 7317-7326. http://dx.doi.org/10.1063/1.476150

[77] Filipovich, V.N., Kalinina, A.M. and Sycheva, G.A. (1975) Temperature Dependence of the Rate of Nucleation of Acicular Crystals in Sodium Silicate Glass. Izvesttiya Akademii Nauk SSSR Neorganicheskie Materialy, 11, 1305-1308. (In Russian)

[78] Fokin, V.M. and Yuritsyn, N.S. (1997) The Nucleation and Growth Rates of Sodium Metasilicate Crystals in Sodium Silicate Glass $44 \mathrm{Na}_{2} \mathrm{O}-56 \mathrm{SiO}_{2}$. Fizika $i$ Khimiya Stekla, 23, 236-239. (In Russian)

[79] Burgner, L.L. and Weinberg M.C. (2000) Crystal Nucleation Rates in a $\mathrm{Na}_{2} \mathrm{O}-\mathrm{SiO}_{2} \mathrm{Glass}$ Journal of Non-Crystalline Solids, 261, 163-168. http://dx.doi.org/10.1016/S0022-3093(99)00597-9

[80] Sycheva, G.A. (1998) Evalution of the Surface Energy at the Crystal-Glass Interface in Sodium Silicate Glass $4 \mathrm{Na}_{2} \mathrm{O}-54 \mathrm{SiO}_{2}$. Fizika i Khimiya Stekla, 24, 47-53.

[81] Burnett, D.G. and Douglas, R.W. (1971) Nucleation and Crystallization in the Soda-Baria-Silica System. Physics and Chemistry of Glasses, 12, 117-124.

[82] Strnad, Z. and Douglas, R.W. (1973) Nucleation and Crystallization in the Soda-Lime-Silica System. Physics and Chemistry of Glasses, 14, 33-36.

[83] Lakshmi Narayan, K. and Kelton, K.F. (1997) First Measurements of Time-Dependent Nucleation as a Function of Composition in $\mathrm{Na}_{2} \mathrm{O} \cdot 2 \mathrm{CaO} \cdot 3 \mathrm{SiO}_{2}$ Glasses. Journal of NonCrystalline Solids, 220, 222-230. http://dx.doi.org/10.1016/S0022-3093(97)00276-7

[84] Potapov, O.V., Fokin, V.M., Suslova, L.Y., Filipovich, V.N. and Ugolkov, V.L. (2000) Influence of $\mathrm{Na}_{2} \mathrm{O}$ Content on the Nucleation Kinetics in Glasses of Composition Close to the $\mathrm{Na}_{2} \mathrm{O} \cdot 2 \mathrm{CaO} \cdot 3 \mathrm{SiO}_{2}$ Stoichiometry. Fizika i Khimiya Stekla, 26, 39-47.

[85] Sycheva, G.A. (1999) Nucleation Kinetics of Lithium Metasilicate in Photosensitive Lithium Aluminosilicate Glass. Fizika i Khimiya Stekla, 25, 501-511.

[86] Filipovich, V.N., Kalinina, A.M. and Sycheva, G.A. (1981) Catalyzed Crystallization of Py- 
roxene Glasses. Fizika i Khimiya Stekla, 7, 55-60. (In Russian)

[87] Sycheva, G.A. and Nasedkin, V.V. (1992) Some Physica-Chemical Parameters of Volcanic Glass Formation. In: Nasedkin, V.V., Ed., Perlite Genesis, Nauka, Moscow, 188 p, 129-125. (In Russian)

[88] Sycheva, G.A. (1997) Influence of Tungsten and Molybdenum Oxides on the Crystallization Kinetics of Tin (II) Pyrophosphate in the $\mathrm{SnO}-\mathrm{SnO}_{2}-\mathrm{ZnO}-\mathrm{P}_{2} \mathrm{O}_{5}$ System. Fizika i Khimiya Stekla, 23, 368-375.

[89] Sycheva, G.A. (1998) Surface Energy at the Crystal Nucleus-Glass Interface in Alkali Silicate Glasses. Fizika i Khimiya Stekla, 24, 342-347.

[90] Sycheva, G.A. and Sigaev, V.N. (1997) Crystallization Kinetics in Ca, Sr and Ba Borophosphate Systems. Proceedings of the 2nd International Conference on Borate Glasses, Crystals and Melts, 554s, 254-260.

[91] Hinz, W. and Kunth, P. (1960) Vitrokeramprodukte mit niedrigem Warmeausdehnungskoeffizienten. Silikattechnik, 11, 506-511.

[92] Vogel, W. and Gerth, K. (1962) Catalyzed Crystallization in Glass. Proceedings of the Symposium on Nucleation and Crystallization in Glasses and Melts, Columbus, April 1961, 11-22.

[93] Filipovich, V.N. (1963) Initial Stages of Crystallization of Glasses and Formation of Glass Ceramics. In: Stekloobraznoe sostoyanie, Vyp. 1: Katalizirovannaya kristallizatsiya stekla [Vitreous State, Vol. 1: Catalyzed Crystallization in Glass], Nauka, Moscow, 9-24 (In Russian)

[94] Maurer, R. (1962) Crystal Nucleation in a Glass Containing Titanium. Journal of Applied Physics, 33, 2132-2139. http://dx.doi.org/10.1063/1.1728909

[95] Ohlberg, S.M., Golob H.R. and Strichler, D. (1962) Crystal Nucleation by Glass in Glass Separation. Proceedings of the Symposium on Nucleation and Crystallization in Glasses and Melts, Columbus, April 1961, 55-62.

[96] Stookey, C.D. (1959) Catalyzed Crystallization of Glass in Theory and Practice. Industrial \& Engineering Chemistry, 51, 805-808. http://dx.doi.org/10.1021/ie50595a022

[97] Nakagawa, K. and Izumitani, T. (1969) Relationship between Phase Separation and Crystallization in $\mathrm{Li}_{2} \mathrm{O}-2.5 \mathrm{SiO}_{2}$ Glass and a Lithium Silicate Containing a Large Amount of Titanium Oxide. Physics and Chemistry of Glasses, 10, 179-184.

[98] Phillips, S.V. and McMillan, P.W. (1965) Phase Separation and Crystallization in $\mathrm{Li}_{2} \mathrm{O}-\mathrm{SiO}_{2}$ Glass and $\mathrm{Li}_{2} \mathrm{O}-\mathrm{SiO}_{2}-\mathrm{P}_{2} \mathrm{O}_{5}$ Glasses. Glass Technology, 6, 46-51.

[99] Tomozawa, M. (1973) Liquid Phase Separation and Crystal Growth in $\mathrm{Li}_{2} \mathrm{O}-\mathrm{SiO}_{2}$ Glass. Physics and Chemistry of Glasses, 14, 112-113.

[100] Milyukov, E.M. (1965) On the Phase Separation and Micro Crystallization of Glasses in $\mathrm{Li}_{2} \mathrm{O}-\mathrm{SiO}_{2}$ and $\mathrm{Li}_{2} \mathrm{O}-\mathrm{Al}_{2} \mathrm{O}_{3}-\mathrm{SiO}_{2}$ Systems. Optiko-Mekhanicheskaya Promishlennost, 31-36. (In Russian)

[101] Harper, H., James, P.F. and McMillan P.W. (1970) Crystal Nucleation in Lithium Silicate Glasses. Discussions of the Faraday Society, 50, 200-205. http://dx.doi.org/10.1039/df9705000206

[102] Sycheva, G.A. (2009) Formation of the Bubble Structure in the $26 \mathrm{Li}_{2} \mathrm{O}-74 \mathrm{SiO}_{2}$ Glass. Glass Physics and Chemistry, 35, 267-273. http://dx.doi.org/10.1134/S1087659609030055

[103] Sycheva, G.A. (2009) Influence of the Presence of Bubbles on the Parameters of Crystal Nucleation in the $26 \mathrm{LI}_{2} \mathrm{O}-74 \mathrm{SiO}_{2}$ Glass. Glass Physics and Chemistry, 35, 602-612. http://dx.doi.org/10.1134/S1087659609060091 
[104] Mel'nichenko, T.D., Rizak, V.M., Mel'nichenko ,T.N. and Fedelesh, V.I. (2004) Parameters of the Fluctuation Free Volume Theory for Glasses in the Ge-As-Se System. Glass Physics and Chemistry, 30, 406-414. http://dx.doi.org/10.1023/B:GPAC.0000045920.01447.ba

[105] Holler, W.S., Blackburn, D.H. and Simmons, J.H. (1974) Miscibility Gaps in Alkali-Silicate Binaries-Data and Thermodynamic Interpretation. American Ceramic Society Bulletin, 57, 120-126. http://dx.doi.org/10.1111/j.1151-2916.1974.tb10832.x

[106] Andreev, N.S., Mazurin, O.V., Porai-Koshits, E.A., Roskova, G.P. and Filipovich, V.N. (1974) Yavleniya likvatsii v steklakh. Nauka, Leningrad. Translated under the Title Phase Separation in Glasses, 1984, North-Holland, Amsterdam.

[107] Mazurin, O.V., Raskova, G.P., Aver'yanov, V.I. and Antropova, T.V. (1991) Dvukhfaznye stekla: Struktura, svoistva, primenenie [Two-Phases Glasses: Structure, Properties, and Applications]. Varshal, B.G., Ed., Nauka, Leningrad.

[108] Braetsch, V. and Frischta, G.H. (1987) Crystallization and Phase Separation in the System $\mathrm{Li}_{2} \mathrm{O}-\mathrm{SiO}_{2}$. Journal of Non-Crystalline Solids, 95-96, 457-462.

http://dx.doi.org/10.1016/S0022-3093(87)80144-8

[109] Burgner, L.L., Weinberg, M.C. and Symmons, J.H. () Early Stage Crystallization Kinetics of Lithium Disilicate and Sodium Silicate Glasses. Final Report of US Department of Energy Grant DE-FG03ER45500, The University of Arizona, Tucson, 85721.

[110] Ardell, A.S. (1972) The Effect of Volume Fraction on Particle Coarsening: The Theoretical Consideration. Acta Metallurgica, 20, 61-71.

http://dx.doi.org/10.1016/0001-6160(72)90114-9

Submit or recommend next manuscript to SCIRP and we will provide best service for you:

Accepting pre-submission inquiries through Email, Facebook, LinkedIn, Twitter, etc.

A wide selection of journals (inclusive of 9 subjects, more than 200 journals)

Providing 24-hour high-quality service

User-friendly online submission system

Fair and swift peer-review system

Efficient typesetting and proofreading procedure

Display of the result of downloads and visits, as well as the number of cited articles

Maximum dissemination of your research work

Submit your manuscript at: http://papersubmission.scirp.org/

Or contact jcpt@scirp.org 